\title{
Global data set of biogenic VOC emissions calculated by the MEGAN model over the last 30 years
}

\author{
K. Sindelarovaa ${ }^{1,2}$, C. Granier ${ }^{1,3,4,5}$, I. Bouarar ${ }^{5}$, A. Guenther ${ }^{6}$, S. Tilmes ${ }^{7}$, T. Stavrakou ${ }^{8}$, J.-F. Müller ${ }^{8}$, U. Kuhn ${ }^{9, *}$, \\ P. Stefani ${ }^{10}$, and W. Knorr ${ }^{11}$ \\ ${ }^{1}$ UPMC Univ. Paris 06; Université Versailles St-Quentin; CNRS/INSU; LATMOS-IPSL, Paris, France \\ ${ }^{2}$ Department of Meteorology and Environment Protection, Faculty of Mathematics and Physics, Charles University in Prague, \\ Prague, Czech Republic \\ ${ }^{3}$ Cooperative Institute for Research in Environmental Sciences, University of Colorado, Boulder, Colorado, USA \\ ${ }^{4}$ NOAA Earth System Research Laboratory, Chemical Sciences Division, Boulder, CO, USA \\ ${ }^{5}$ Max Planck Institute for Meteorology, Hamburg, Germany \\ ${ }^{6}$ Pacific Northwest National Laboratory, Atmospheric Sciences and Global Change Division, Richland, WA, USA \\ ${ }^{7}$ National Center for Atmospheric Research, Boulder, USA \\ ${ }^{8}$ Belgian Institute for Space Aeronomy, Brussels, Belgium \\ ${ }^{9}$ Biogeochemistry Department, Max Planck Institute for Chemistry, Mainz, Germany \\ ${ }^{10}$ University of Tuscia, Department of Forest Science and Environment, Viterbo, Italy \\ ${ }^{11}$ Department of Physical Geography and Ecosystem Science, Lund University, Lund, Sweden \\ *now at: Multiphase Chemistry Department, Max Planck Institute for Chemistry, Mainz, Germany
}

Correspondence to: K. Sindelarova (katerina.sindelarova@latmos.ipsl.fr)

Received: 20 February 2014 - Published in Atmos. Chem. Phys. Discuss.: 29 April 2014

Revised: 1 August 2014 - Accepted: 6 August 2014 - Published: 9 September 2014

\begin{abstract}
The Model of Emissions of Gases and Aerosols from Nature (MEGANv2.1) together with the ModernEra Retrospective Analysis for Research and Applications (MERRA) meteorological fields were used to create a global emission data set of biogenic volatile organic compounds (BVOC) available on a monthly basis for the time period of 1980-2010. This data set, developed under the Monitoring Atmospheric Composition and Climate project (MACC), is called MEGAN-MACC. The model estimated mean annual total BVOC emission of $760 \mathrm{Tg}(\mathrm{C}) \mathrm{yr}^{-1}$ consisting of isoprene $(70 \%)$, monoterpenes $(11 \%)$, methanol (6\%), acetone (3\%), sesquiterpenes $(2.5 \%)$ and other BVOC species each contributing less than $2 \%$.

Several sensitivity model runs were performed to study the impact of different model input and model settings on isoprene estimates and resulted in differences of up to $\pm 17 \%$ of the reference isoprene total. A greater impact was observed for a sensitivity run applying parameterization of soil moisture deficit that led to a $50 \%$ reduction of isoprene emissions
\end{abstract}

on a global scale, most significantly in specific regions of Africa, South America and Australia.

MEGAN-MACC estimates are comparable to results of previous studies. More detailed comparison with other isoprene inventories indicated significant spatial and temporal differences between the data sets especially for Australia, Southeast Asia and South America. MEGAN-MACC estimates of isoprene, $\alpha$-pinene and group of monoterpenes showed a reasonable agreement with surface flux measurements at sites located in tropical forests in the Amazon and Malaysia. The model was able to capture the seasonal variation of isoprene emissions in the Amazon forest.

\section{Introduction}

Non-methane volatile organic compounds (VOCs) are released into the atmosphere as a result of anthropogenic activity as well as biochemical processes in soils, oceans and vegetation. Terrestrial vegetation is the dominant source of 
atmospheric VOCs accounting for about $90 \%$ of the emission total (Guenther et al., 1995). Isoprene and monoterpenes are the most abundant species among the biogenic VOCs (Kesselmeier and Staudt, 1999; Lathière et al., 2006; Guenther et al., 2012). Biogenic VOCs (BVOCs) are an important atmospheric constituent affecting both gas phase and heterogeneous chemistry of the troposphere. Due to high reactivity their atmospheric chemical lifetime ranges from minutes to hours (or days for several oxygenated species) (Atkinson and Arey, 2003). Modelling studies have identified their substantial impact on the tropospheric budget of atmospheric key species such as carbon monoxide (CO), hydroxyl radical (OH) and low-level ozone (Granier et al., 2000; Poisson et al., 2000; Pfister et al., 2008), thus influencing the oxidative capacity of the atmosphere (Houweling et al., 1998; Taraborrelli et al., 2012) on regional as well as global scales. By affecting the concentration of low-level ozone, BVOCs have impact on regional air quality (e.g. Simpson, 1995; Pierce et al., 1998; Curci et al., 2009; Sartelet et al., 2012) and through tropospheric ozone radiative forcing on climate (e.g. Chalita et al., 1996; Brasseur et al., 1998; Gauss et al., 2006). In addition to the significance in the gas-phase chemistry, oxidative products of some biogenic VOCs may undergo a phase transition and form secondary organic aerosol (SOA) (Hoffmann et al., 1997; Griffin et al., 1999; Limbeck et al., 2003; van Donkelaar et al., 2007) having important consequences in the Earth's radiation budget.

Due to their importance for atmospheric chemical processes, the estimation of the amounts of biogenic VOCs emitted into the atmosphere is needed for proper representation of their role in global and regional chemical transport models. Several modelling approaches have been developed for estimation of BVOC emissions (Guenther et al., 1995; Martin et al., 2000; Niinemets et al., 1999; Arneth et al., 2007b). In our study we have applied the most recent version of the Model of Emissions of Gases and Aerosols from Nature (MEGANv2.1) (Guenther et al., 2012).

MEGAN is a model system calculating temporal and spatial rates of emission of chemical compounds from terrestrial ecosystems to the atmosphere under varying environmental conditions. Although emissions from biomass burning can also be attributed to natural sources, these are not accounted for in the MEGAN model.

The basis for the model algorithm has already been presented by Guenther et al. (1991, 1993, 1995, 2006) who defined the flux $F$ ( $\mu$ g grid cell ${ }^{-1} \mathrm{~h}^{-1}$ ) of a chemical species emitted from a model grid cell as a product of its emission potential under standard environmental conditions $\epsilon$ $\left(\mu \mathrm{g} \mathrm{m}^{-2} \mathrm{~h}^{-1}\right.$, i.e. basal emission potential at leaf temperature of $30{ }^{\circ} \mathrm{C}$ and photosynthetic photon flux density of $1000 \mu \mathrm{mol} \mathrm{m}^{-2} \mathrm{~s}^{-1}$ ) assigned to a grid cell ecosystem type, grid cell surface area $S\left(\mathrm{~m}^{2}\right)$ and a dimensionless emission activity factor $\gamma$ which represents dependence of the emis- sion on environmental conditions.

$F=\epsilon \cdot S \cdot \gamma$

The first model version (Guenther et al., 1995) considered the effect of both light and temperature on isoprene emission rates but only the temperature dependence of emissions for all other compounds. It included a simple canopy radiative transfer model differentiating between the conditions of sunlit and sun-shaded leaves at multiple canopy levels. As experimental findings describing new factors influencing VOC emissions were appearing, the model algorithm was being updated. Guenther et al. (1999) introduced a simple leaf age activity factor which parameterizes the seasonal variation of plant foliage and modified the temperature activity factor to capture the dependence of emissions on past meteorological conditions (temperature and light).

Guenther et al. introduced the acronym MEGAN for the model version MEGANv2.0 detailed in Guenther et al. (2006). The model simulates net emission rates accounting for losses of primary emissions in the canopy. It uses canopy scale emission factors that can be based on above canopy flux measurements or are extrapolated into the canopy scale from the leaf and branch level measurements using the builtin canopy environment model for predefined standard environmental conditions. The canopy model estimates incident solar radiation and temperature at five canopy levels as a weighted average for all leaves and includes a leaf energy balance model. The model algorithm has been updated with more sophisticated leaf age activity factor for deciduous land cover types accounting for different emission rates in four developmental stages of the foliage going from leaf budbreak to leaf senescence. Reflecting the measurements of isoprene emissions under drought conditions, MEGAN also introduced a parameterization of isoprene emission reduction due to soil moisture deficit.

Sakulyanontvittaya et al. (2008) developed a US regional emission factor database for monoterpenes and sesquiterpenes and extended the MEGAN model to simulate emissions of these chemical species (MEGANv2.02). Previous studies have shown that these compounds are to a large extent emitted in a manner similar to that of isoprene, i.e. depending on both temperature and light. Sakulyanontvittaya et al. therefore introduced a light dependence factor assigned to each modelled species in order to simulate different levels of light-emission dependence.

The current version of the MEGAN model (MEGANv2.1) described in Guenther et al. (2012) updates the model approach and parameterizations of MEGANv2.02. It calculates the net primary emission of 19 compound classes which are then decomposed into 147 individual species such as isoprene, monoterpene and sesquiterpene compounds, carbon monoxide, methanol, alkanes, alkenes, aldehydes, acids, ketones and other oxygenated VOCs. Using the MEGAN postprocessing tool, the species can be lumped into the compound groups of common chemical mechanisms for use in 
chemical transport models. MEGANv2.1 is available in two versions. The stand-alone version requires the user to provide meteorological input data as well as inputs on vegetation description. When running the version coupled with the Community Land Model (CLM4.0) (Lawrence et al., 2011), land cover distribution and meteorological inputs can be provided by the dynamic vegetation and atmospheric models of the Community Earth System Model (CESM) (Gent et al., 2011).

During the past few years, the MEGAN model has been widely used within the scientific community for the estimation of BVOC emissions and has been incorporated into various earth system and chemistry transport models (e.g. Guenther et al., 2006; Heald et al., 2008; Pfister et al., 2008; Stavrakou et al., 2009; Emmons et al., 2010; Millet et al., 2010; Guenther et al., 2012).

The long-term data set presented in this paper has been developed in support of the MACC (Monitoring Atmospheric Composition and Climate project: http://www.gmes-atmosphere.eu) project and of the CCMI (Chemistry-Climate Model Initiative: http://www.met.reading.ac.uk/ccmi/). The MEGAN model setting and selection of input data are addressed in Sect. 2, description of the emission data set (MEGAN-MACC) and a set of model sensitivity studies focusing on isoprene is given in Sect. 3. Comparison of MEGAN-MACC emission estimates with results of previous studies is presented in Sect. 4 with special attention to isoprene and its temporal and spatial distributions in different data sets. In Sect. 5 we show a comparison of modelled emission fluxes with measurements in tropical forests in the Amazon and in Borneo. Conclusions are presented in Sect. 6 .

\section{Emission model description and model inputs}

\subsection{Algorithm of the emission estimation}

The emission data set presented here has been calculated by the stand-alone version of MEGANv2.1. The BVOC species emission flux $\left(\mu \mathrm{g} \mathrm{m}^{-2} \mathrm{~h}^{-1}\right)$ is estimated following Eq. (1). The emission activity factor is calculated as follows:

$\gamma=C_{\mathrm{ce}} \cdot \mathrm{LAI} \cdot \gamma_{\mathrm{P}} \cdot \gamma_{\mathrm{T}} \cdot \gamma_{\mathrm{A}} \cdot \gamma_{\mathrm{SM}} \cdot \gamma_{\mathrm{CO}_{2}}$,

where $C_{\text {ce }}$ is a canopy environment coefficient $(=0.57)$ serving to normalize $\gamma$ to 1 at standard canopy conditions described in the following paragraph. LAI is the leaf area index $\left(\mathrm{m}^{2} \mathrm{~m}^{-2}\right)$, and $\gamma_{\mathrm{P}}$ and $\gamma_{\mathrm{T}}$ are emission activity factors accounting for light and temperature effects, respectively. $\gamma_{\mathrm{P}}$ is calculated based on the photosynthetic photon flux density (PPFD) ( $\mu \mathrm{mol}$ of photons in $400-700 \mathrm{~nm}$ range $\mathrm{m}^{-2} \mathrm{~s}^{-1}$ ). PPFD is part of the solar radiation in the spectral range of 400-700 nm, which can be processed by plants during photosynthesis. Both $\gamma_{\mathrm{P}}$ and $\gamma_{\mathrm{T}}$ are divided into the light dependent (LD) and light independent (LI) parts using the light depen- dence fraction factor (LDF) as defined by Sakulyanontvittaya et al. (2008) and Guenther et al. (2012).

$\gamma_{\mathrm{P}}=(1-\mathrm{LDF})+\mathrm{LDF} \cdot \gamma_{\mathrm{P} \_\mathrm{LD}}$

$\gamma_{\mathrm{T}}=(1-\mathrm{LDF}) \cdot \gamma_{\mathrm{T}_{-} \mathrm{LI}}+\mathrm{LDF} \cdot \gamma_{\mathrm{T}_{-} \mathrm{LD}}$

The $\gamma_{\mathrm{P}}$ and $\gamma_{\mathrm{T}}$ factors are calculated by the MEGAN full canopy environment model, which simulates the propagation of light and vertical change in temperature within the canopy on five vertical levels. Both $\gamma_{\mathrm{P}}$ and $\gamma_{\mathrm{T}}$ factors account for the impact of temperature and light conditions in the past $24 \mathrm{~h}$. The $\gamma_{\mathrm{A}}$ and $\gamma_{\mathrm{SM}}$ factors represent the leaf age emission activity factor and the dependence of isoprene emission on soil moisture, respectively, already introduced in MEGANv2.0. The $\gamma_{\mathrm{CO}_{2}}$ factor is a new MEGANv2.1 model feature, which accounts for the impact of concentration of carbon dioxide $\left(\mathrm{CO}_{2}\right)$ on isoprene emission. Following the parameterization of Heald et al. (2009), isoprene emissions decrease when ambient $\mathrm{CO}_{2}$ concentration increases above the level of $400 \mathrm{ppmv}$ (parts per million by volume). In view of the lack of clear experimental evidence of an effect, $\gamma_{\mathrm{CO}_{2}}$ is set to 1 for all other species.

The canopy scale emissions of the MEGAN model are standardized at LAI equal to $5 \mathrm{~m}^{2} \mathrm{~m}^{-2}$ for a canopy consisting of $80 \%$ mature, $10 \%$ growing and $10 \%$ old leaves. Further standard canopy conditions include a solar angle equal to $60^{\circ}$, transmission of PPFD through the atmosphere (i.e. ratio between PPFD at the top of the canopy and at the top of the atmosphere) equal to 0.6 , air temperature of $303 \mathrm{~K}$, air humidity equal to $14 \mathrm{~g} \mathrm{~kg}^{-1}$, wind speed equal to $3 \mathrm{~m} \mathrm{~s}^{-1}$ and soil moisture of $0.3 \mathrm{~m}^{3} \mathrm{~m}^{-3}$ for current canopy environmental conditions; and for average canopy environmental conditions of the past $24 \mathrm{~h}$ leaf temperature of $297 \mathrm{~K}$, PPFD of 200 and $50 \mu \mathrm{mol} \mathrm{m}^{-2} \mathrm{~s}^{-1}$ for sunlit and shaded leaves, respectively. Guenther et al. (2012) provide more detail on the model algorithm.

\subsection{Model input parameters}

Unless otherwise stated, in all model simulations the effect of $\mathrm{CO}_{2}$ concentration on isoprene emission represented by $\gamma_{\mathrm{CO}_{2}}$ in Eq. (2) was taken into account. We have applied the factor calculated as a global average for each year using the annual mean of $\mathrm{CO}_{2}$ concentrations observed at Mauna Loa and South Pole stations (Keeling et al., 2012).

\subsubsection{Meteorological fields}

The MEGAN model was driven by meteorological fields of Modern-Era Retrospective Analysis for Research and Applications (MERRA) provided by the NASA's Goddard Space Flight Center (Rienecker et al., 2011). MERRA data are produced by the Goddard Earth Observing System (GEOS) atmospheric model version 5.2.0 with a data assimilation system (DAS). The full data set covers the modern satellite era 
from 1979 to present. In this work we used data for the period of 1980 to 2010.

For the reference MEGAN model simulation (MEGANMACC) we have used 6 hourly instantaneous analysis fields of surface temperature, air pressure, humidity and wind speed given on the model grid with horizontal spatial resolution of $0.5^{\circ}$ latitude and $0.666^{\circ}$ longitude. Since the MEGAN model requires hourly input data, the 6 hourly fields were interpolated. Spatial resolution of the meteorological fields was shown to have a negligible impact on global isoprene emissions, however, it might cause a significant isoprene variations at local and regional scales (Pugh et al., 2013). Calculating hourly meteorological data from 6 hourly inputs can lower the global isoprene emissions by up to $3 \%$ and using monthly averages of hourly daily profile might lead to additional decrease of $7 \%$ globally. Temporal averaging of meteorological inputs can have more substantial impacts at regional level (Ashworth et al., 2010).

The MERRA data set does not directly provide the photosynthetic photon flux density (PPFD) needed for calculation of the $\gamma_{P}$ factor in Eq. (2). Values of PPFD can be obtained from photosynthetically active radiation (PAR, W $\mathrm{m}^{-2}$ ) provided on hourly basis by the MERRA Land model. As discussed in Guenther et al. (2012), selection of a conversion factor between PAR and PPFD is an important issue. In MEGAN, conversion factors of 4.6 and $4.0 \mu \mathrm{mol}$ photons $\mathrm{J}^{-1}$ are used for diffuse and direct radiation, respectively.

In the reference MEGAN model run the effect of the soil moisture deficit on BVOC emission was not taken into account and the $\gamma_{S M}$ factor was assigned to 1. Impact of the soil moisture activity factor on isoprene emission is further discussed together with the sensitivity data set S4 in Sect. 3.2.4.

\subsubsection{Vegetation and emission factors}

Vegetation composition inside the model domain is the principal information needed to estimate BVOC emissions. A distribution of 16 plant functional types (PFT) consistent with the vegetation categories used in the Community Land Model version 4 (CLM4) (Lawrence and Chase, 2007) was used to define the vegetation spatial distribution in our model setup. The data set provides a percentage of PFT coverage in each model grid cell.

Another important input parameter is the emission potential $\epsilon$ of individual modelled species. In MEGANv2.1, there are two possibilities for assigning a grid cell with an emission potential value. One option is to use the global gridded highresolution emission potential maps $\left(\epsilon_{\mathrm{MAP}}\right)$ provided together with the MEGAN model code for the predominant BVOC species. These gridded maps were compiled on the basis of detailed land cover and plant species distributions and took into account the information from species specific flux measurements (Guenther et al., 2012). The second option is to calculate $\epsilon$ based on the plant functional type composition in the grid cell. Each of the PFT categories is assigned a value representing the average basal emission of all BVOC species from this ecosystem type (emission factor $\mathrm{EF}$ ). The emission potential $\epsilon_{\mathrm{PFT}}$ of a grid cell is then calculated as follows:

$\epsilon_{\mathrm{PFT}}=\sum_{i=1}^{16} \mathrm{EF}_{i} \cdot f_{i}$,

where $f$ is a fraction of a grid cell covered by PFT category $i$.

In our model runs, we used the emission potential from the gridded maps $\left(\epsilon_{\mathrm{MAP}}\right)$ for isoprene, $\alpha$-pinene, $\beta$-pinene, $\Delta 3$ carene, limonene, myrcene, ocimene, sabinene and 2-methyl3-buten-2-ol (MBO). For other modelled species we used calculated emission potentials $\epsilon_{\mathrm{PFT}}$. A list of PFT categories together with the corresponding prescribed emission factor values (EF) for modelled chemical species can be found in Table 2 in Guenther et al. (2012).

The density of vegetation is represented in the model by gridded values of leaf area index (LAI). LAI is defined as the surface of the leaf area per unit surface of the ground $\left(\mathrm{m}^{2} \mathrm{~m}^{-2}\right)$. We have used the 8-day high spatially resolved LAI data processed by Yuan et al. (2011) from global retrievals of the Moderate-Resolution Imaging Spectroradiometer (MODIS, Collection 5) for the period of 20002009. Yuan et al. applied a quality control algorithm in order to decrease uncertainties and inconsistencies. The 8-day LAI values averaged over the 10 -year period were used for the MEGAN model simulations from 1980-1999 and for the year 2010 for which LAI values from satellite observation were not available. Using climatological LAI instead of the actual LAI values can lead to about $5 \%$ emission difference. Since LAI data are mean values over the whole grid cell, we have divided the grid mean LAI by a fraction of the vegetated surface to take into account only the parts of the grid cell covered by vegetation. A similar LAI modification was applied in Guenther et al. (2006) and Müller et al. (2008). We have set the LAI maximum at $7 \mathrm{~m}^{2} \mathrm{~m}^{-2}$ to avoid very high LAI values for the sparsely vegetated grid cells.

LAI values are used directly in calculation of the emission activity factor $\gamma$ as well as in calculation of the leaf age activity factor $\gamma_{\mathrm{A}}$ (Eq. 2). The current age of the vegetation foliage is parameterized based on changes between the current LAI and LAI in the preceding time step (Guenther et al., 2012).

Maps of PFT distribution and emission potentials $\epsilon_{\text {MAP, }}$, as well as LAI input files were regridded to the spatial resolution of the meteorological fields (i.e. $0.5^{\circ} \times 0.666^{\circ}$ ). Regridding to lower spatial resolution might cause inaccuracies, especially in coastal areas and locations with high variety of land cover types (Pugh et al., 2013). 
Table 1. Annual global total averaged over the period of 1980-2010 for selected BVOC species (with standard deviation $\sigma$ ), their relative contribution to the global total of all BVOCs expressed as emission of carbon, maximal and minimal value within the modelled period. Note that the sum of monoterpenes already includes emissions of $\alpha$-pinene and $\beta$-pinene (in italics).

\begin{tabular}{lcrrr}
\hline $\begin{array}{l}\text { Global totals } \\
\text { Species }\end{array}$ & $\begin{array}{c}\text { mean } \\
\mathrm{Tg} \text { (species) } \mathrm{yr}^{-1}\end{array}$ & $\begin{array}{r}\text { rel. contribution } \\
\%\end{array}$ & $\begin{array}{r}\text { minimum } \\
\mathrm{Tg} \mathrm{yr}^{-1}\end{array}$ & $\begin{array}{r}\text { maximum } \\
\mathrm{Tg} \mathrm{yr}^{-1}\end{array}$ \\
\hline isoprene & $594 \pm 34$ & 69.2 & 520 & 672 \\
sum of monoterpenes & $95 \pm 3$ & 10.9 & 89 & 103 \\
$\alpha$-pinene & $32 \pm 1$ & 3.7 & 30 & 34 \\
$\beta$-pinene & $16.7 \pm 0.6$ & 1.9 & 15.6 & 17.9 \\
sesquiterpenes & $20 \pm 1$ & 2.4 & 18 & 23 \\
methanol & $130 \pm 4$ & 6.4 & 121 & 138 \\
acetone & $37 \pm 1$ & 3.0 & 35 & 40 \\
ethanol & $19 \pm 1$ & 1.3 & 17 & 21 \\
acetaldehyde & $19 \pm 1$ & 1.3 & 17 & 21 \\
ethene & $18.1 \pm 0.5$ & 2.0 & 17.1 & 19.2 \\
propene & $15.0 \pm 0.4$ & 1.7 & 14.1 & 15.9 \\
formaldehyde & $4.6 \pm 0.2$ & 0.2 & 4.3 & 5.1 \\
formic acid & $3.5 \pm 0.2$ & 0.1 & 3.2 & 3.8 \\
acetic acid & $3.5 \pm 0.2$ & 0.1 & 3.2 & 3.8 \\
2-methyl-3-buten-2-ol & $1.6 \pm 0.1$ & 0.1 & 1.4 & 1.8 \\
toluene & $1.5 \pm 0.1$ & 0.2 & 1.4 & 1.6 \\
other VOC species & $8.5 \pm 0.3$ & 0.8 & 7.9 & 9.0 \\
\hline CO & $90 \pm 4$ & - & 82 & 97 \\
\hline
\end{tabular}

\section{Emission model results and sensitivity simulations}

\subsection{Spatial and temporal distribution of emissions over the last 30 years}

Monthly mean emissions of 22 chemical species emitted from biogenic sources including isoprene, monoterpenes, sesquiterpenes, methanol, other oxygenated VOCs and carbon monoxide were calculated by the MEGANv2.1 model on a global $0.5^{\circ} \times 0.5^{\circ}$ grid for the time period of 1980-2010 .

Global annual totals of individual species averaged over the considered period are listed in Table 1, together with the minimum and maximum emissions for the past 3 decades. The mean annual amount emitted for all listed biogenic VOCs reaches $760 \mathrm{Tg}(\mathrm{C}) \mathrm{yr}^{-1}$ with isoprene accounting for $70 \%$, sum of monoterpenes for $11 \%$, methanol for $6 \%$ and other VOCs for $14 \%$ of the BVOC total expressed as the emission of carbon. The mean annual global total of carbon monoxide (CO) is $90 \mathrm{Tg}(\mathrm{CO}) \mathrm{yr}^{-1}$. Species considered in the sum of monoterpenes are $\alpha$-pinene, $\beta$-pinene, limonene, trans- $\beta$-ocimene, myrcene, sabinene and $\Delta 3$-carene and their mean relative contribution to the monoterpene sum is presented in Fig. 1.

The spatial distribution of MEGAN-MACC emissions of isoprene and the sum of monoterpenes in January and July are displayed in Fig. 2. Zonal averages of isoprene monthly mean emissions for the period of January 1980 to December 2010 are shown in the top panel of Fig. 3. The temporal profile of global monthly emission totals is presented in

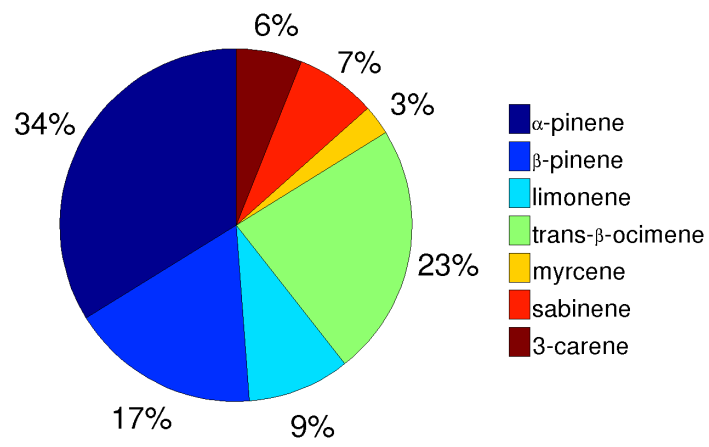

Figure 1. Relative contribution of monoterpene species to monoterpene annual global total averaged over the 1980-2010 period. Considered monoterpene species are listed in the enclosed legend.

the mid panel and the bottom panel shows inter-annual variability of isoprene annual global totals. As shown in Figs. 2 and 3, isoprene is mainly emitted in the south-tropical region, which contributes about $56 \%$ to the global total, followed by northern tropics (32\%) and northern and southern temperate regions contributing with $7 \%$ and $4 \%$, respectively. Less than $1 \%$ of global isoprene is emitted in the northern Arctic. The dominance of the south tropical region is reflected also in the distribution of isoprene emissions between Northern and Southern Hemisphere where the latter is a source of about $60 \%$ of the global total isoprene. The difference between the highest emission annual total of $672 \mathrm{Tg} \mathrm{yr}^{-1}$ (1983) and the 
a)
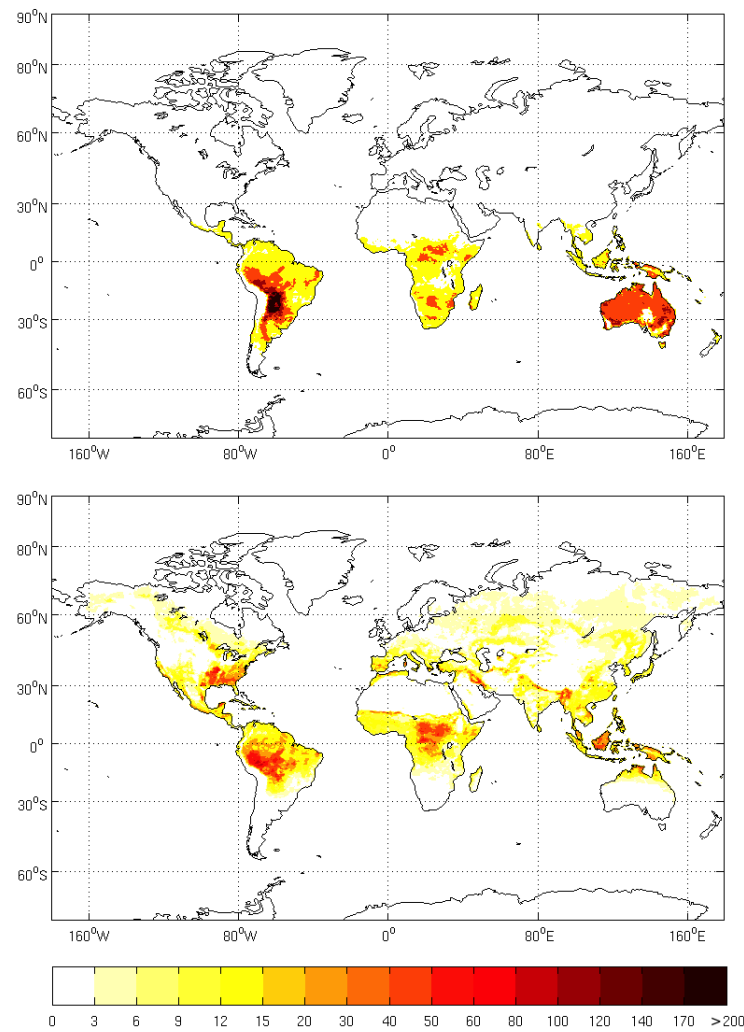

b)
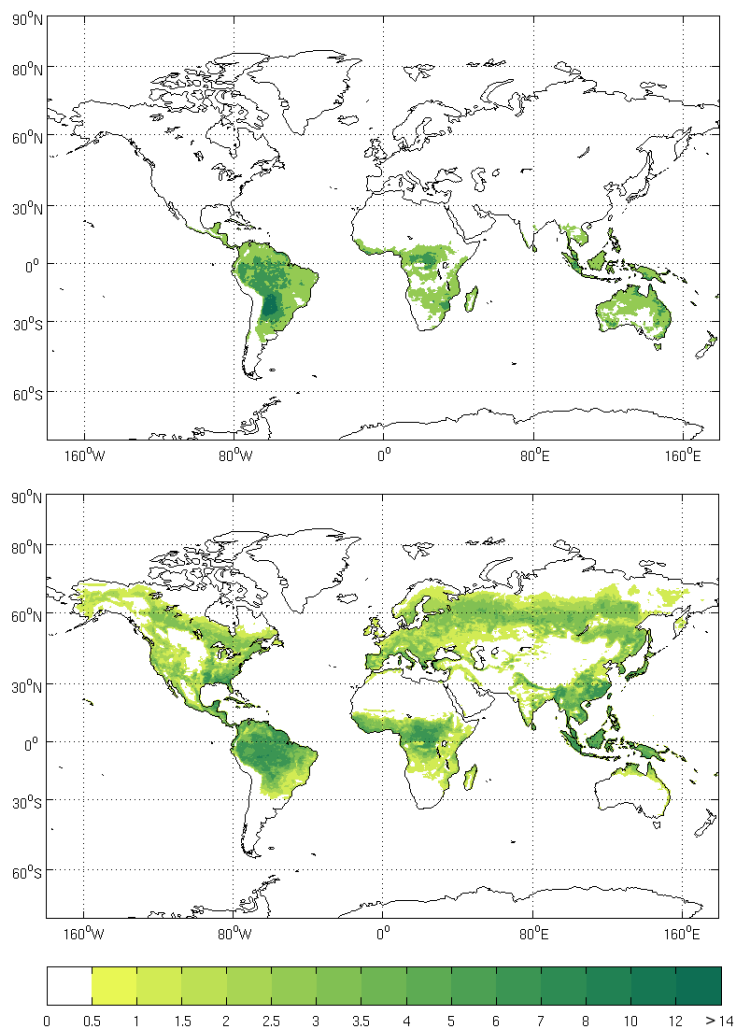

Figure 2. Spatial distribution of monthly mean emissions of (a) isoprene, (b) monoterpenes, $\left(\mathrm{mg} \mathrm{m}^{-2}\right.$ day $^{-1}$ ) for January (top) and July (bottom) averaged over the modelled period 1980-2010 calculated by the MEGAN model.

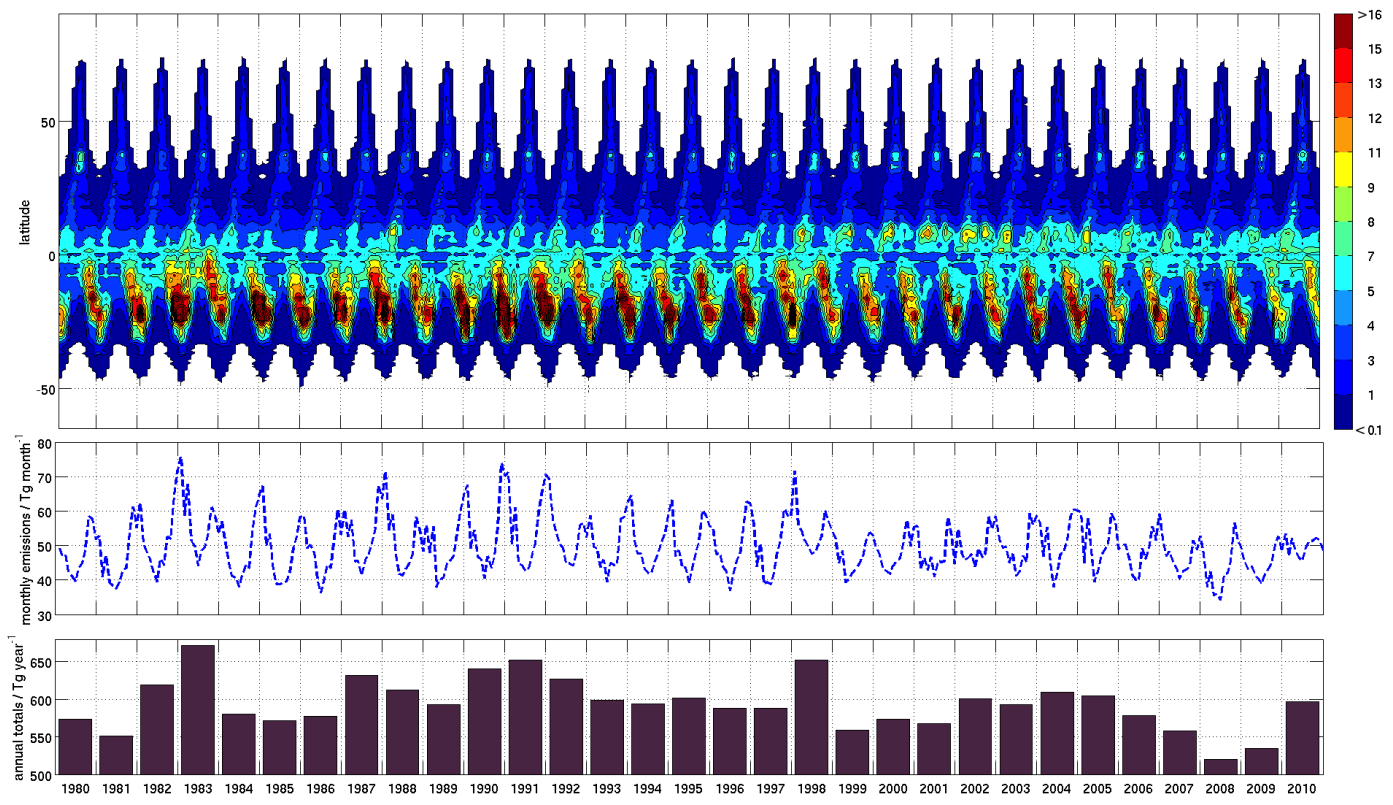

Figure 3. Zonal averages of monthly mean isoprene emissions $\left(\mathrm{mg} \mathrm{m}^{-2} \mathrm{day}^{-1}\right)$ (top panel), temporal profile of isoprene global monthly totals $\left(\mathrm{Tg} \mathrm{month}{ }^{-1}\right)$ (mid-panel), global annual totals of isoprene $\left(\mathrm{Tg} \mathrm{yr}^{-1}\right.$ ) (bottom panel) for the period of 1980-2010 from the MEGANMACC data set. Note that the vertical axis for annual totals starts at $500 \mathrm{Tg}^{-1}$. 


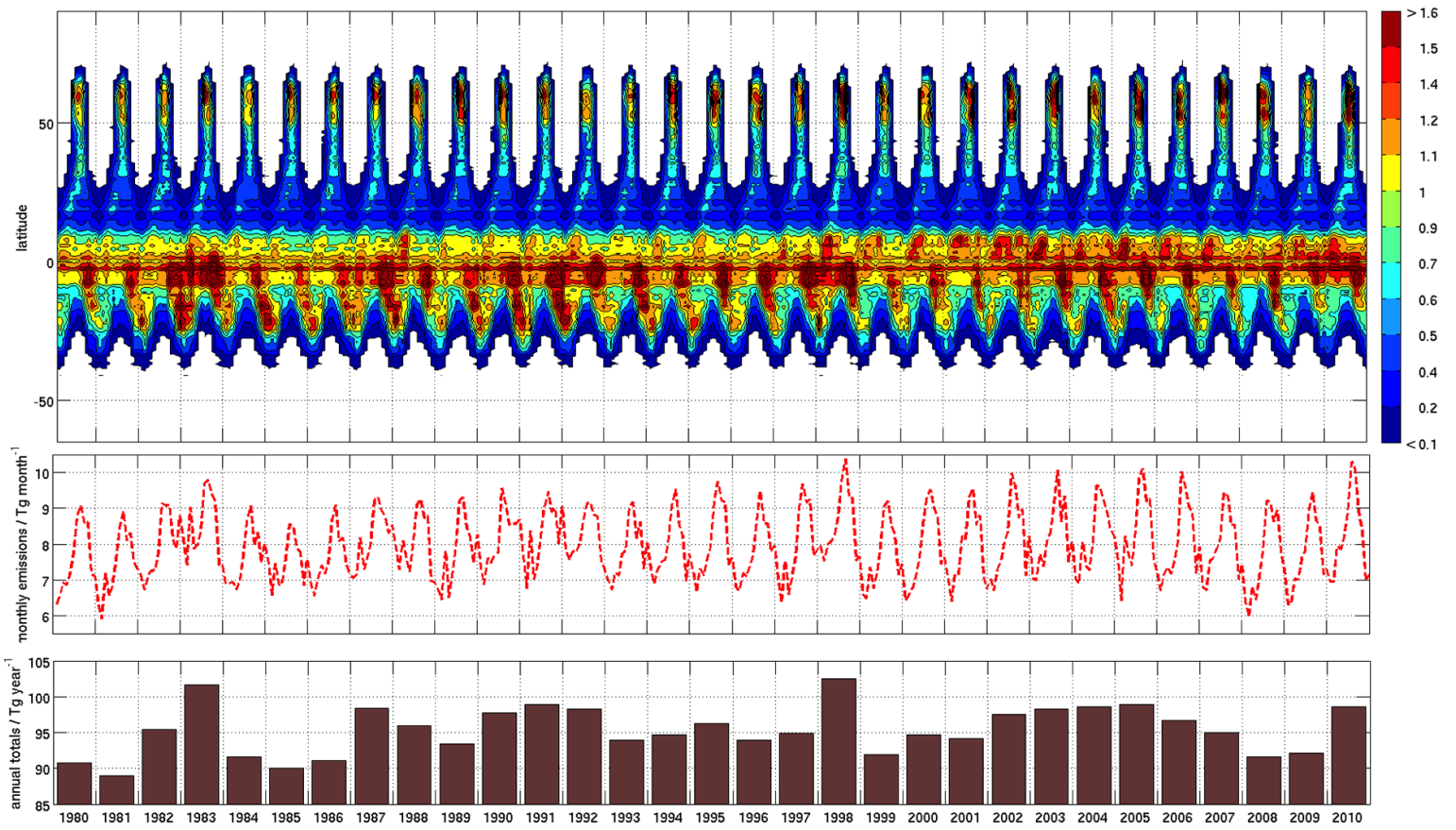

Figure 4. Zonal averages of monthly mean monoterpene emissions ( $\mathrm{mg} \mathrm{m}^{-2} \mathrm{day}^{-1}$ ) (top panel), temporal profile of monoterpene global monthly totals ( $\mathrm{Tg} \mathrm{month}^{-1}$ ) (mid-panel), global annual totals of monoterpene ( $\mathrm{Tg} \mathrm{yr}^{-1}$ ) (bottom panel) for the period of 1980-2010 from the MEGAN-MACC data set. Note that the vertical axis for annual totals starts at $85 \mathrm{Tg}^{-1}$.

lowest of $520 \mathrm{Tg} \mathrm{yr}^{-1}$ (2008) is about $29 \%$ of the isoprene total emission averaged over the modelling period.

Results for the group of monoterpenes are shown in Fig. 4. The upper panel showing zonally averaged emissions highlights the main emitting regions, i.e. the southern and northern tropics contributing to the global total with $48 \%$ and $35 \%$, respectively. There is also a significant source of monoterpenes in the northern temperate region $(13 \%)$. The southern temperate region contributes about $3 \%$ and the northern Arctic less than $2 \%$. The distribution of monoterpene emissions between the two hemispheres is more or less equal. The annual maximum of monoterpene emissions is reached during the Northern Hemisphere summer when the emissions from northern latitudes reach their annual maximum. The inter-annual variation in global annual monoterpene totals is smaller than for isoprene, and the difference between the highest emitting year $1998\left(102 \mathrm{Tg} \mathrm{yr}^{-1}\right)$ and the lowest emitting year $1981\left(89 \mathrm{Tg} \mathrm{yr}^{-1}\right)$ is only $15 \%$ of mean annual monoterpene emissions.

The relative contribution of each latitudinal band to the global isoprene and monoterpene totals over the course of the year (averaged for the 1980-2010 period) is presented in Fig. 5. The graphs indicate the dominance of the tropical region throughout the year for both species, and the higher contribution of the northern temperate and Arctic region to monoterpene totals when compared to isoprene.

For both isoprene and monoterpenes, the predominant sources of emissions are the broadleaf tropical forests (broadleaf evergreen and deciduous trees) - with a relative contribution of $84.5 \%$ and $77 \%$, respectively. For isoprene, the second largest source corresponds to temperate shrubs $(10 \%)$ followed by cool and warm grass $(4 \%)$ and finally needleleaf forest in boreal regions with $1.5 \%$. Shrubs and needleleaf forest contribute equally to monoterpene emissions with about $10 \%$. Grass is only a minor monoterpene source with $0.5 \%$ of total monoterpene emission.

The MEGAN-MACC emission inventory is available for download at the Emission of atmospheric Compounds and Compilation of Ancillary Data database (ECCAD, http://www.pole-ether.fr/eccad). ECCAD is an online database of global and regional emission inventories. It includes anthropogenic, biogenic and biomass burning emission data together with a list of ancillary data such as population density, land cover maps and fire emission proxies. The website provides an online display and analysis tools as well as an interface for the download of user specified data.

\subsection{Sensitivity of isoprene emissions to different factors}

In this section we present the variability of emission estimates due to selection of model input parameters. We focus on emissions of isoprene - the most abundant BVOC species and the species for which there is the most information available. As previously shown by Guenther et al. (2006) and Arneth et al. (2011), isoprene emissions are very sensitive to the driving meteorological data, especially temperature and 
Table 2. List of sensitivity runs performed.

\begin{tabular}{clc}
\hline sensitivity study & description & model parameter \\
\hline S1 & use of LAI from MERRA data set & $\gamma$ and $\gamma_{\mathrm{A}}$ \\
S2 & use of isoprene emission potential $\epsilon$ PFT & $\epsilon$ \\
S3 & no impact of $\mathrm{CO}_{2}$ on isoprene & $\gamma_{\mathrm{CO}_{2}}$ \\
S4 & impact of soil moisture on isoprene & $\gamma_{\mathrm{SM}}$ \\
S5 & input PAR estimated from short-wave radiation & $\gamma_{\mathrm{P}}$ \\
\hline
\end{tabular}
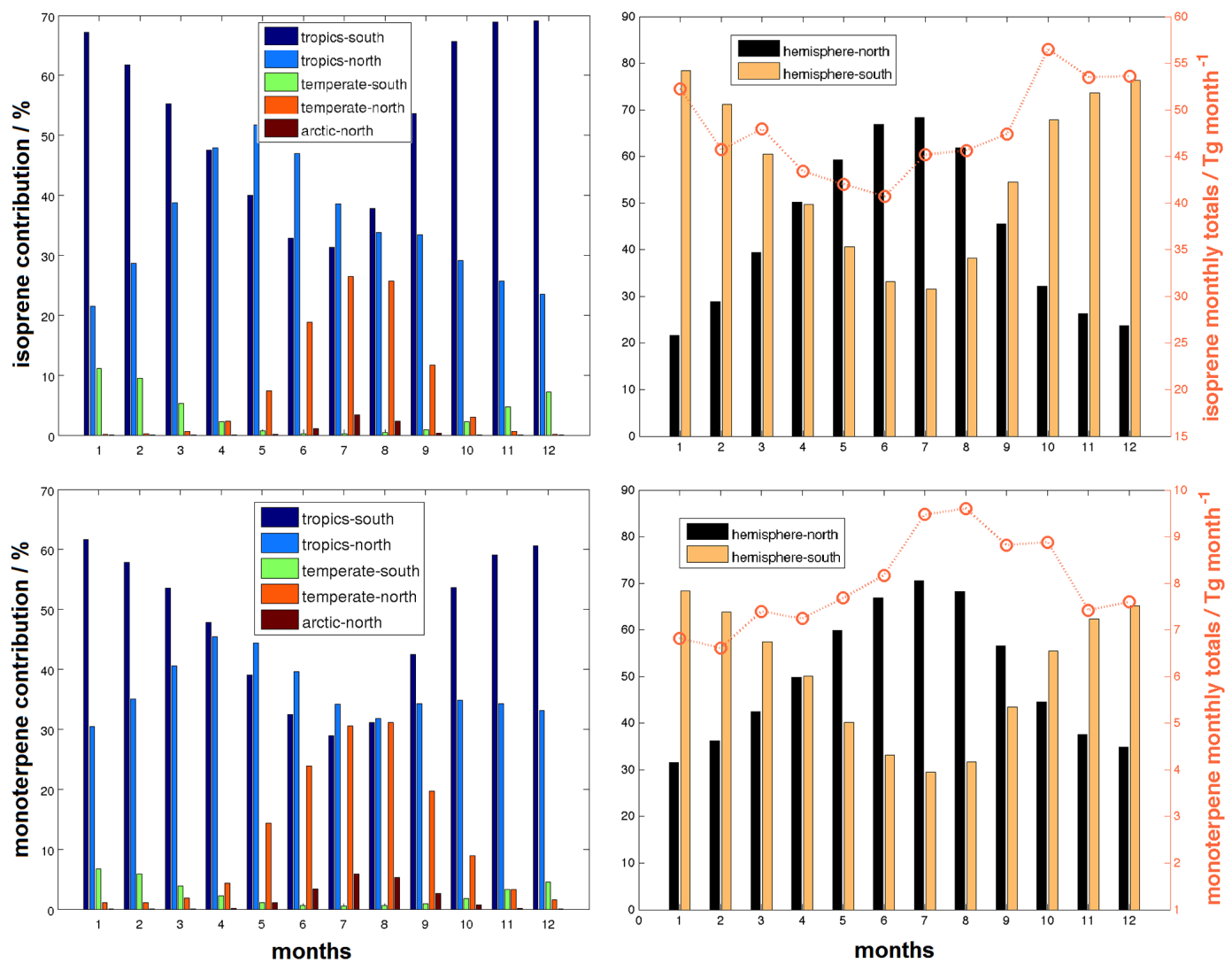

Figure 5. Relative monthly contribution of south-tropical $\left(29.5-0.5^{\circ} \mathrm{S}\right)$, north-tropical $\left(0.5-29.5^{\circ} \mathrm{N}\right)$, south-temperate $\left(59.5-30.5^{\circ} \mathrm{S}\right)$, northtemperate $\left(30.5-59.5^{\circ} \mathrm{N}\right)$ and north-arctic $\left(60.5-89.5^{\circ} \mathrm{N}\right)$ regions (left) and relative monthly contribution of Southern $\left(89.5-0.5^{\circ} \mathrm{S}\right)$ and Northern $\left(0.5-89.5^{\circ} \mathrm{N}\right)$ Hemisphere (right) to global emission total of isoprene (top) and monoterpenes (bottom). Colours assigned to each latitudinal band are given in the enclosed legend. Emission totals are averaged over the period 1980-2010.

solar radiation. In our study, we have performed five sensitivity studies in order to evaluate the uncertainties of isoprene emission resulting from the uncertainties of selected parameters of the emission model. We have investigated the emissions provided by MEGAN for different LAI input data (S1), with modified isoprene emission potential inputs (S2), studied the impact of $\mathrm{CO}_{2}$ concentration on isoprene emission (S3), the inclusion of soil moisture activity factor (S4) and the use of a simple calculation of PAR variable from shortwave solar radiation (S5). All sensitivity runs were driven by meteorology and LAI data for the year 2003. Table 2 gives a list of performed studies and indicates the parameter in
Eq. (2) that has been modified from the reference MEGAN model setting in each study.

\subsubsection{Leaf area index}

In order to evaluate the influence of different sources of LAI data used in the MEGAN model, MODIS values were replaced by leaf area index from the MERRA reanalysis data set in the sensitivity run S1. MERRA-LAI is calculated by the Land module of the MERRA model system. When compared to LAI from MODIS (MODIS-LAI), MERRALAI is generally higher. The largest differences, i.e. about 
$1.2 \mathrm{~m}^{2} \mathrm{~m}^{-2}$ are found in the Amazon, the western coast of the US, Canada, northern Europe and Australia.

\subsubsection{Input emission potential of isoprene}

Isoprene emission potential values $\epsilon_{\mathrm{PFT}}$ (described in Sect. 2.2.2 and calculated following Eq. (5)) were used in sensitivity run S2 instead of emission potentials from gridded maps $\left(\epsilon_{\mathrm{MAP}}\right)$. On the global scale isoprene emission potentials $\epsilon_{\mathrm{PFT}}$ are about $14 \%$ lower than emission potentials $\epsilon_{\text {MAP. }}$ The largest difference is again over the region of Australia with a relative decrease of $47 \%$ when compared to

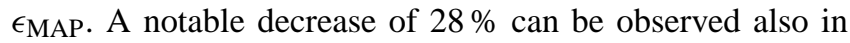
southern Africa, further in sub-Saharan Africa and in the southeast US. On the contrary, $\epsilon_{\mathrm{PFT}}$ is higher than $\epsilon_{\mathrm{MAP}}$ in South America, especially in northern Amazon (+10\%), and in Europe except for Spain and Portugal $(+18 \%)$.

The differences between the two emission potential databases lie in the different land cover types and emission factors serving as a basis for their calculation. While the land cover data set for $\epsilon_{\mathrm{PFT}}$ consists of 16 generalized plant functional type categories (e.g. broadleaf deciduous tropical forest, needleleaf evergreen boreal forest), each with specific emission factors, the land cover serving as a basis for the $\epsilon_{\text {MAP }}$ consists of more than 2000 ecoregions with specific emission factors (Guenther et al., 2012). The detailed land cover associated with $\epsilon_{\text {MAP }}$ includes individual tree and shrub species for some, but not all, regions to account for differences among strongly emitting tree species and tree species with negligible emissions belonging to the same generalized PFT category (e.g. broadleaf deciduous temperate forest) with appropriate emission factors. Emission factors for $\epsilon_{\mathrm{PFT}}$ and $\epsilon_{\mathrm{MAP}}$ are similar when averaged over large scales but they can differ greatly for specific locations.

\subsection{3 $\mathrm{CO}_{2}$ inhibition factor}

The atmospheric $\mathrm{CO}_{2}$ concentration has significantly increased during the past decades and is predicted to further increase in the future. Global modelling studies simulating future isoprene emissions have shown that including an algorithm that accounts for inhibition of the isoprene emissions from plants due to elevated $\mathrm{CO}_{2}$ concentration can significantly diminish the predicted isoprene increase (e.g. Heald et al., 2009). However, recent studied suggest that this inhibition may not occur in warmer climate (Sun et al., 2013) and a better understanding of this process is needed. MEGAN model simulates the impact of $\mathrm{CO}_{2}$ on isoprene emission through activity factor $\gamma_{\mathrm{CO}_{2}}$ (Eq. 2) defined by Heald et al. (2009) as follows:

$\gamma_{\mathrm{CO}_{2}}=I_{\mathrm{Smax}}-\left[\left(I_{\mathrm{S} \max }\left(0.7 \cdot C_{\mathrm{a}}\right)^{h}\right) /\left(\left(C^{*}\right)^{h}+\left(0.7 \cdot C_{\mathrm{a}}\right)^{h}\right)\right]$,

where $I_{\text {Smax }}(=1.344), h(=1.4614)$ and $C^{*}(=585)$ are empirical coefficients and $C_{\mathrm{a}}$ is the ambient $\mathrm{CO}_{2}$ concentration. The formula assumes that internal $\mathrm{CO}_{2}$ concentration within the plant tissue is $70 \%$ of $C_{\mathrm{a}}$. The $\gamma_{\mathrm{CO}_{2}}$ factor decreases nonlinearly with increasing $\mathrm{CO}_{2}$ concentration and it is normalized to 1 for the ambient $\mathrm{CO}_{2}$ concentration of $400 \mathrm{ppmv}$. The global mean $\mathrm{CO}_{2}$ concentration for the year 2003 was $373.1237 \mathrm{ppmv}$ which corresponds to $\gamma_{\mathrm{CO}_{2}}=1.0277$. In order to quantify the importance of the $\mathrm{CO}_{2}$ inhibition factor, we have performed sensitivity run $\mathrm{S} 3$, in which the $\gamma_{\mathrm{CO}_{2}}$ factor was assigned to 1 .

\subsubsection{Soil moisture activity factor}

Soil moisture is the principal source of water for plants. Several studies have investigated the impact of drought on various processes ongoing within plants (Tingey et al., 1981; Sharkey and Loreto, 1993; Pegoraro et al., 2004a, b, 2007; Brilli et al., 2007) and have found a clear decline of photosynthetic rate, stomatal conductance and transpiration rate directly after the soil water content decrease. However, the link between isoprene emissions and increasing drought condition is more difficult to identify. Tingey et al. (1981) and Pegoraro et al. (2004b) found that for short-term soil moisture deficit lasting for a couple of days, the isoprene emission rate remains constant or even slightly increases in the initial stages of drought (Pegoraro et al., 2007). But as the soil moisture decreases below a certain level isoprene emission starts to decline as well. A reduction of isoprene emission rate by $64 \%$ after 12 days of severe drought was observed for live-oak plants (Quercus virginiana Mill.) by Pegoraro et al. (2004b) as well as a decrease by $50 \%$ after 5 days (Tingey et al., 1981). The experimental findings of Pegoraro et al. (2004a) served as a base for the parameterization of the impact of soil moisture stress on isoprene emissions in the MEGAN model. The soil moisture activity factor $\gamma_{\mathrm{SM}}$ used in Eq. (2) is defined as follows:
$\gamma_{\mathrm{SM}}=1$
$\Theta>\Theta_{1}$
$\gamma_{\mathrm{SM}}=\left(\Theta-\Theta_{\mathrm{W}}\right) / \Delta \Theta_{1}$
$\Theta_{\mathrm{W}}<\Theta<\Theta_{1}$
$\gamma_{\mathrm{SM}}=0$
$\Theta<\Theta_{\mathrm{W}}$

where $\Theta$ is a volumetric water content $\left(\mathrm{m}^{3} \mathrm{~m}^{-3}\right), \Theta_{\mathrm{W}}$ is a wilting point, i.e. the limiting value of soil moisture below which the plant cannot absorb water from soil, $\Delta \Theta_{1}$ is an empirical coefficient $(=0.06)$, and $\Theta_{1}=\Theta_{\mathrm{W}}+\Delta \Theta_{1}$ (Guenther et al., 2006, 2012). In order to quantify the effect of soil moisture, we have conducted the S4 sensitivity calculation. We have used the gridded MERRA wilting point values and root zone soil moisture. The wilting point $\Theta_{\mathrm{W}}$ is dependent on the soil type, and we have used the 2-D MERRA gridded data, constant in time, with values varying from 0.01 to $0.28 \mathrm{~m}^{3} \mathrm{~m}^{-3}$. Root zone soil moisture $\left(\mathrm{m}^{3} \mathrm{~m}^{-3}\right)$ is an averaged volumetric water content $\Theta$ in the root zone. Depending on the location on the globe the model root zone depth varies from 0.75 to $1 \mathrm{~m}$. Root zone soil moisture content is provided in hourly time resolution. The spatial distribution 


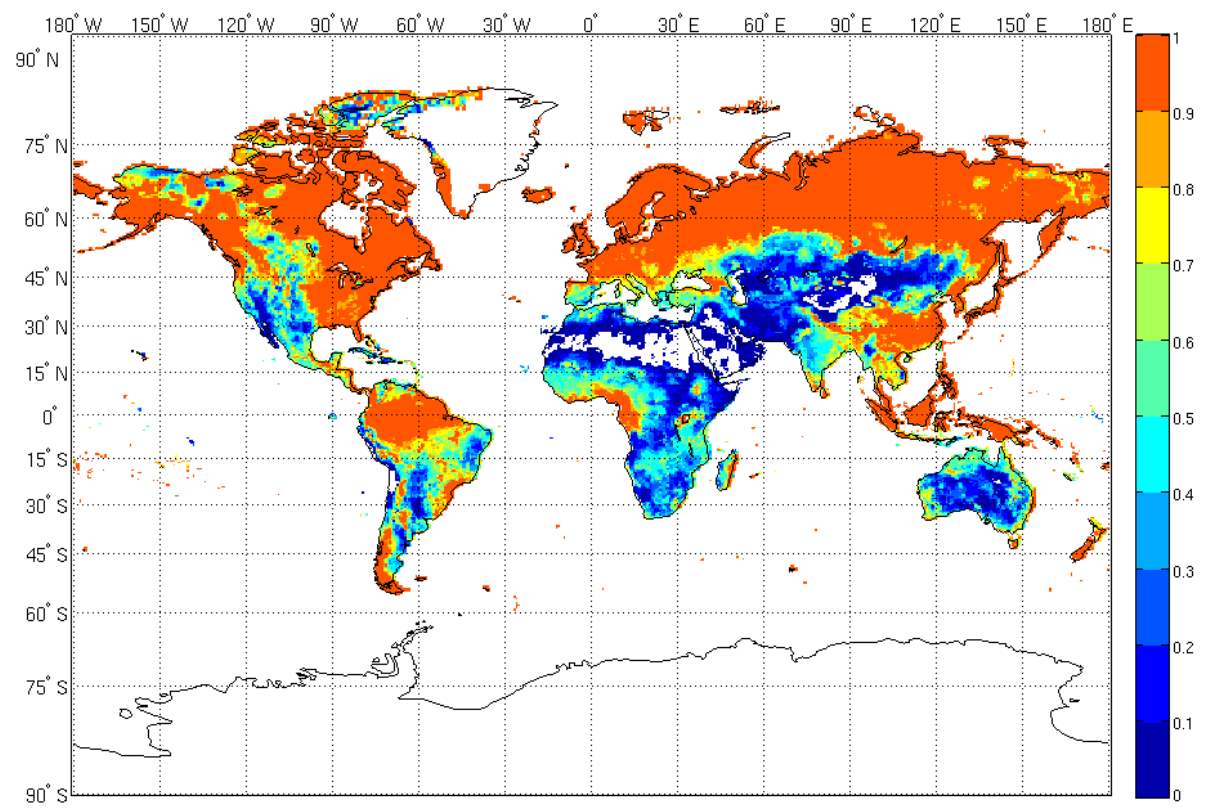

Figure 6. Spatial distribution of the soil moisture dependence factor $\gamma_{\mathrm{SM}}$ for isoprene emission. Annual average for the year 2003.

of the annual mean soil moisture activity factor $\gamma_{\mathrm{SM}}$ for the year 2003 is shown in Fig. 6.

\subsubsection{Photosynthetically active radiation from shortwave solar radiation}

Since isoprene emissions are strongly affected by photosynthesis, the photosynthetically active radiation (PAR) is an essential parameter for the estimation of isoprene emissions. In the reference MEGANv2.1 simulations, we have used the PAR provided by the MERRA reanalysis.

Distributions of PAR are not always archived from meteorological or climatological model simulations, and a common practice to estimate PAR has been to calculate it as a fraction of the total incoming shortwave solar radiation (SW). Based on measurements in different parts of the globe, the ratio of PAR/SW usually ranges from 0.45 to 0.5 (e.g. Rao, 1984; Papaioannou et al., 1993; Jacovides et al., 2003) and varies in time and space. R. Pinker and co-workers at the University of Maryland (USA) developed a method to derive surface spectral radiative components from satellite observations collected under the International Satellite Cloud Climatology Project (Schiffer and Rossow, 1983). Comparison of the three methods to derive PAR is shown in Fig. 7: the annual mean PAR from the MERRA data set is compared with PAR provided by University of Maryland and with PAR calculated as half of incoming shortwave radiation. The MERRA data set provides higher PAR values over Australia, central Africa and southern America (about $20 \%$ ) and on the other hand lower PAR over the equatorial Amazon and Gulf of Guinea $(\sim 20 \%)$ when compared to PAR from the satellite. There is much better agreement between the PAR derived from satellite and from the MERRA reanalysis than with the PAR calculated from SW.

In order to evaluate the difference between the isoprene emissions calculated based on PAR modelled by MERRA model and PAR estimated with the assumption of PAR/SW ratio to be equal to 0.5 we have performed a sensitivity run S5 using the latter parameterization in the input to MEGAN model.

\subsubsection{Results of the sensitivity simulations}

Comparison of the results of the reference (MEGANMACC) and sensitivity simulations $\mathrm{S} 1-\mathrm{S} 5$ is presented in Fig. 8. Global annual totals of isoprene were divided into contributions of each of nine geographical regions defined as in GlobEmission project (http://www.globemission.eu/). Figure 8 shows the isoprene emissions from each region for the reference and sensitivity runs, and the extent of the GlobEmission regions.

The sensitivity simulations led to total annual isoprene emissions within $\pm 17 \%$ of the reference simulation, except for the S4 simulation introducing the soil moisture effect, which led to a $50 \%$ decrease in the isoprene emission.

The use of MERRA-LAI instead of MODIS-LAI (S1) results in an annual isoprene emission increase of $24 \mathrm{Tg} \mathrm{yr}^{-1}$ (i.e. $+4 \%$ ) when compared to the reference run (REF). The main changes $(66 \%)$ occur in Australia $\left(+16 \mathrm{Tg} \mathrm{yr}^{-1}\right)$, and the remaining $33 \%$ result from changes in South and North America.

Isoprene global total estimates in sensitivity run S2 (impact of emission potentials) decreased by $74 \mathrm{Tg} \mathrm{yr}^{-1}$ $(-12.5 \%)$ mainly due to $41 \mathrm{Tg} \mathrm{yr}^{-1}$ absolute decrease in 
a)

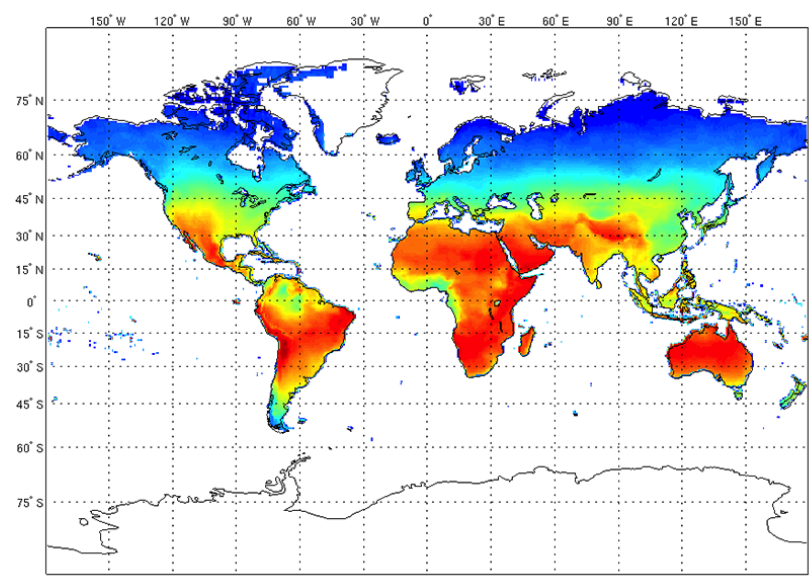

b)

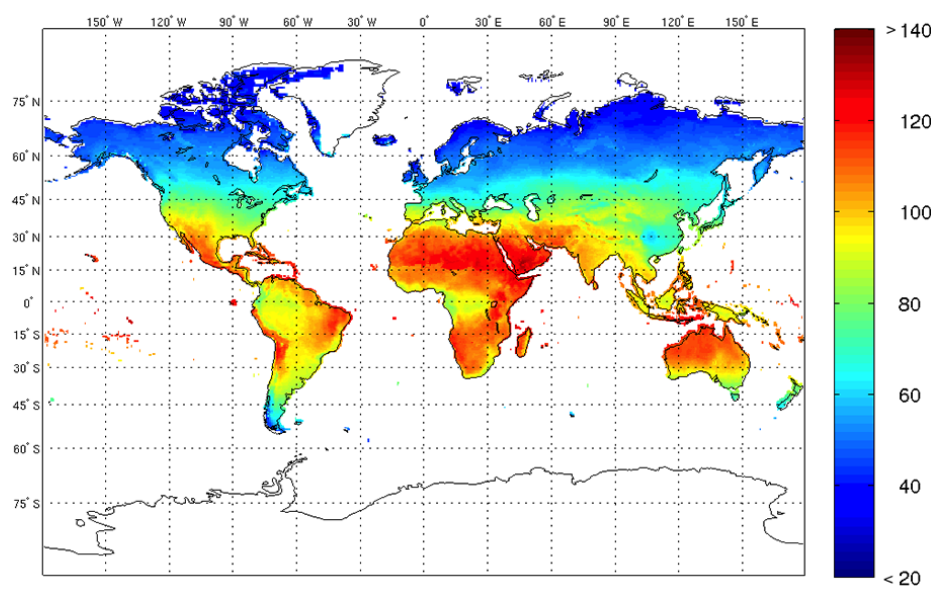

c)

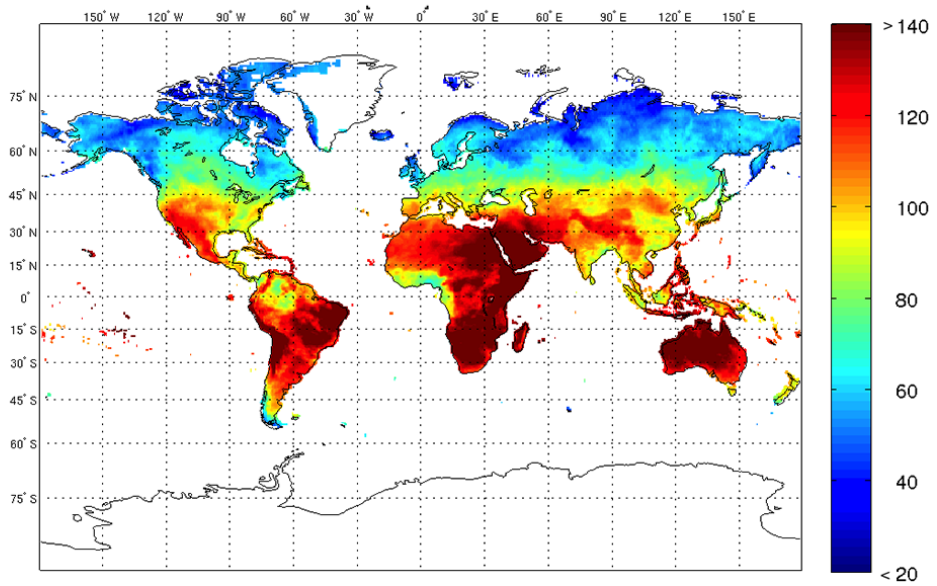

Figure 7. Comparison of photosynthetically active radiation $\left(\mathrm{W} \mathrm{m}^{-2}\right)$ (a) provided by the MERRA reanalysis, (b) derived from satellite observations (University of Maryland, R. Pinker, personal communication, 2012), (c) calculated as half of incoming shortwave solar radiation from MERRA. The annual averages are shown for the year 2005.

Australia and $18 \mathrm{Tg} \mathrm{yr}^{-1}$ in southern Africa. However, for South America the use of PFT-dependent emission factors led to an absolute increase in isoprene emission by $8 \mathrm{Tg} \mathrm{yr}^{-1}$ (i.e. $+4 \%$ ).

Omission of $\mathrm{CO}_{2}$ activity factor $\gamma_{\mathrm{CO}_{2}}$ in the calculation of sensitivity run $\mathrm{S} 3$ resulted in an overall decrease of isoprene emission by $2.7 \%$. Since $\mathrm{CO}_{2}$ concentration for the simulation year 2003 was less than $400 \mathrm{ppmv}$, the inclusion of $\gamma_{\mathrm{CO}_{2}}$ in the MEGAN calculation actually increases isoprene emission $\left(\gamma_{\mathrm{CO}_{2}}\right.$ is greater than 1$)$. However, $\gamma_{\mathrm{CO}_{2}}$ will be an important factor for future simulations when $\mathrm{CO}_{2}$ concentration is predicted to greatly exceed $400 \mathrm{ppmv}$ (e.g. Arneth et al., 2007b; Heald et al., 2009; Young et al., 2009).

The S4 simulation led to large changes in isoprene emissions, when compared to the reference, as indicated in Fig. 9a. The inclusion of the soil moisture algorithm led to a general decrease of isoprene emissions (50\% of the reference run totals), especially in arid and semi-arid regions such as central Africa, southern part of South-American tropical region and Australia where the emission reduction reached up to $70 \%$ with respect to the reference run. This decrease in isoprene emissions is much higher than that presented by Guenther et al. (2006), who applied the same algorithm using NCEP (National Centers for Environmental Prediction) soil moisture values, the 2-D gridded wilting point values from the database of Chen and Dudhia (2001) and PFT dependent determination of the depth of the root zone (Zeng, 2001). They report a $7 \%$ reduction in global annual isoprene emissions. Müller et al. (2008) estimated isoprene emission with the MEGANv2.1 model using the ECMWF (European Centre for Medium-Range Weather Forecasts) soil moisture values and a fixed value of wilting point from the ECMWF model for the whole model domain. The reduction in global isoprene estimates due to soil moisture activity factor was $21 \%$. Different levels of isoprene emission reduction due to soil moisture deficit are caused by the use of different 

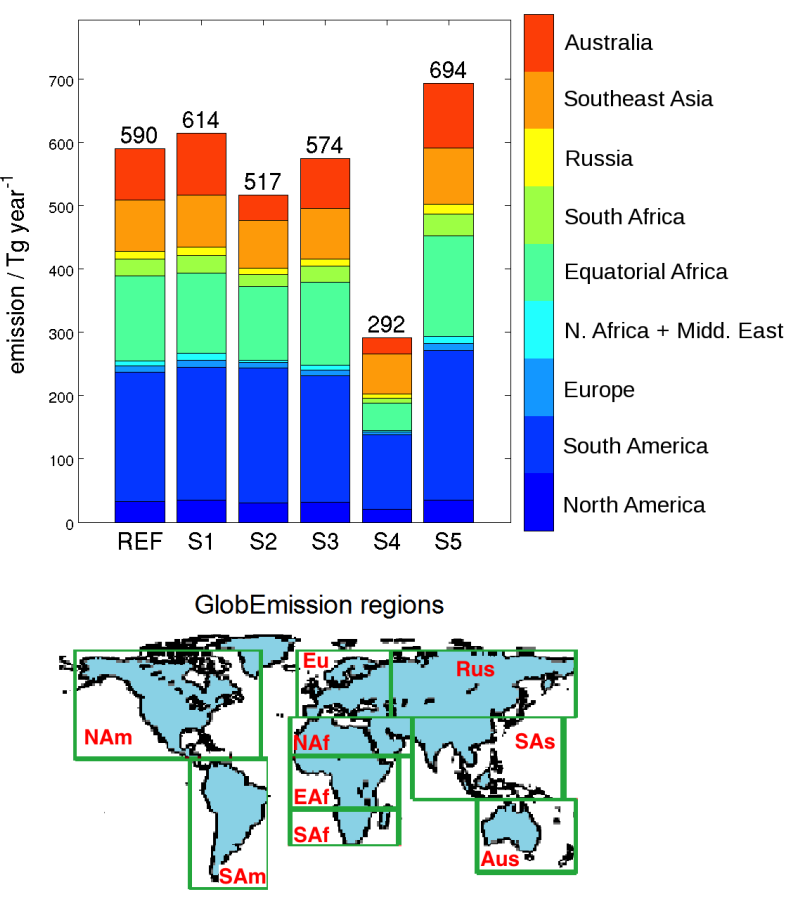

Figure 8. Isoprene emission totals for year 2003 from the reference MEGAN-MACC run and sensitivity runs S1-S5. The absolute contributions of nine geographical regions to global total are shown in the top figure. Colours assigned to each region are defined in the colour bar on the right. The extent of GlobEmission regions (Aus Australia, SAs - Southeast Asia, Rus - Russia, SAf - South Africa, EAf - Equatorial Africa, NAf - North Africa and Middle East, Eu Europe, SAm - South America, NAm - North America) is defined below.

soil moisture databases and different wilting point values in the emitting regions. Wilting point values in South America, central Africa and Australia are $\sim 0.1 \mathrm{~m}^{3} \mathrm{~m}^{-3}$ according to Chen and Dudhia (2001), $0.171 \mathrm{~m}^{3} \mathrm{~m}^{-3}$ in Müller et al. (2008) and $\sim 0.2 \mathrm{~m}^{3} \mathrm{~m}^{-3}$ according to MERRA reanalysis data. This has a significant impact on $\gamma_{\mathrm{SM}}$ since wilting point $\Theta_{\mathrm{W}}$ is a threshold value below which $\gamma_{\mathrm{SM}}$ is set to 0 (Eq. 7). Müller et al. (2008) and Guenther et al. (2012) stressed the necessity of using wilting point values consistent with input soil moisture data since $\Theta_{\mathrm{W}}$ is an important parameter for determining soil characteristics in climate models.

The impact of changes in the calculation of PAR (S5) is displayed in Fig. 9b, which shows the difference in the annual mean isoprene emission between the sensitivity run and the reference. As has already been discussed, since PAR calculated from shortwave radiation is generally higher than PAR from MERRA reanalysis, we also obtain higher emission fluxes in areas with the largest radiation differences. The increase of total isoprene emissions is $104 \mathrm{Tg} \mathrm{yr}^{-1}$ (i.e. $17.5 \%$ compared to the reference run) with the highest absolute contributions from South America, equatorial Africa and
Table 3. Comparison of isoprene emission totals from regional studies (left) and MEGAN-MACC (right). MEGAN-MACC emissions were extracted for the particular region and period of the regional study.

\begin{tabular}{|c|c|c|}
\hline \multirow[t]{2}{*}{ Region } & \multicolumn{2}{|c|}{ isoprene/ $\mathrm{Tg} \mathrm{yr}^{-1}$} \\
\hline & previous studies & this study \\
\hline \multicolumn{3}{|l|}{ South and East Asia } \\
\hline Fu et al. (2007) & $56 \pm 30$ & 73 \\
\hline \multicolumn{3}{|l|}{ China } \\
\hline Klinger et al. (2002) & 4.6 & 9.5 \\
\hline Stavrakou et al. (2014) & 7 & 9.9 \\
\hline Tie et al. (2006) & 7.7 & 9 \\
\hline \multicolumn{3}{|l|}{ Europe } \\
\hline Curci et al. (2009) & $3.2-6$ & 6 \\
\hline Karl et al. (2009) & 3.5 & 8.7 \\
\hline Steinbrecher et al. (2009) & 3.2 & 9.6 \\
\hline \multicolumn{3}{|l|}{ North America } \\
\hline Guenther et al. (2000) & 33.1 & 34.5 \\
\hline \multicolumn{3}{|l|}{ Tropical South America } \\
\hline Barkley et al. (2013) ${ }^{\mathrm{a}}$ & $106 \pm 6$ & 163 \\
\hline Barkley et al. $(2013)^{\mathrm{b}}$ & $64 \pm 3$ & 163 \\
\hline \multicolumn{3}{|l|}{ Central Africa } \\
\hline Guenther et al. (1999) & 40 & 47 \\
\hline \multicolumn{3}{|l|}{ Africa } \\
\hline Marais et al. (2012) & 68 & 150 \\
\hline \multirow[t]{2}{*}{ Region } & \multicolumn{2}{|c|}{ isoprene/ Tg period ${ }^{-1}$} \\
\hline & previous studies & this study \\
\hline \multicolumn{3}{|l|}{ Europe } \\
\hline Curci et al. $(2010)^{\mathrm{c}}$ & 3.0 & 4.4 \\
\hline \multicolumn{3}{|l|}{ North America } \\
\hline Palmer et al. $(2003)^{\mathrm{d}}$ & 6.4 & 5.7 \\
\hline Millet et al. $(2008)^{\mathrm{e}}$ & $13.8-16.5$ & 14.3 \\
\hline $\begin{array}{l}\text { derived from SCIAMACHY; } \\
\text { derived from OMI; } \\
\text { May-September; } \\
\text { July; } \\
\text { June-August. }\end{array}$ & & \\
\hline
\end{tabular}

Australia where isoprene estimates increased by $31,25.5$ and $21.5 \mathrm{Tg} \mathrm{yr}^{-1}$, respectively.

\section{Comparison of MEGAN-MACC inventory with other data sets}

\subsection{Isoprene global and regional totals}

Previous estimates of global total isoprene emissions vary between 412 and $682 \mathrm{Tg} \mathrm{yr}^{-1}$ (Fig. 10). Two of the presented studies, detailed in Shim et al. (2005) $\left(643 \mathrm{Tg} \mathrm{yr}^{-1}\right)$ and Stavrakou et al. (2009) (434 $\left.\mathrm{Tg} \mathrm{yr}^{-1}\right)$, used chemical 
a)

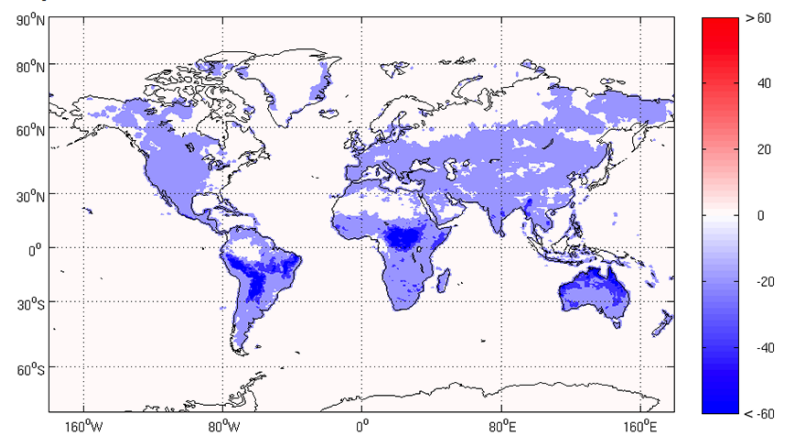

b)

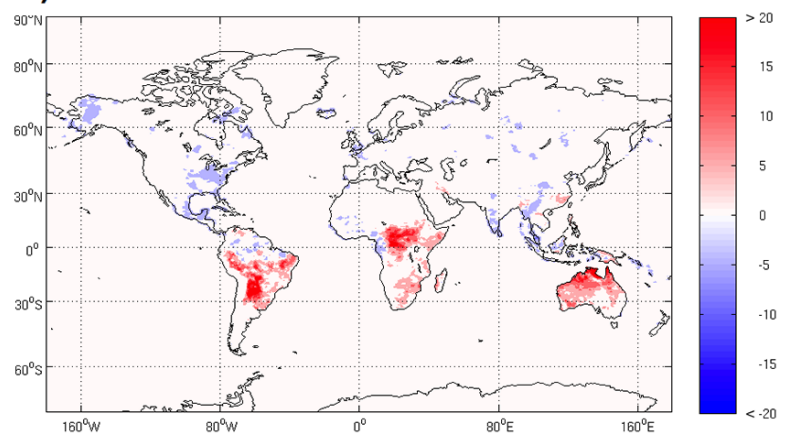

Figure 9. Difference in isoprene annual mean emissions $\left(\mathrm{mg} \mathrm{m}^{-2} \mathrm{day}^{-1}\right)$ between the sensitivity S4 (soil moisture effect) and the reference (left), and between the sensitivity run S5 (sensitivity to PAR) and the reference (right) for the year 2003.

Table 4. Inventories used in the comparison together with applied model system and driving input data. (RF99= Ramankutty and Foley, 1999, M08 = Müller et al., 2008, S14 = Stavrakou et al., 2014, A07 = Arneth et al., 2007a, G06 = Guenther et al., 2006).

\begin{tabular}{llllllll}
\hline Data set & Model & Weather & LAI & PFT & $\begin{array}{l}\text { Emission } \\
\text { potentials } \epsilon\end{array}$ & $\begin{array}{l}\text { Data } \\
\text { availability }\end{array}$ & Reference \\
\hline MEGAN-MACC & MEGANv2.1 & MERRA & MODIS & CLM4 & MEGAN2.1 & $1980-2010$ & This study \\
BISA-bottom-up & MEGANV2.02 & ECMWF & MODIS & MEGAN2 & MEGAN2 & $1995-2009$ & M08 \\
BISA-top-down & MEGANv2.1 & ECMWF & MODIS & RF99 & MEGAN2.1 & $2007-2012$ & S14 \\
GUESS-ES & LPJ-GUESS & CRU & LPJV & LPJV & LPJ-GUESS & $1980-2009$ & A07 \\
MEGANv2 & MEGANv2.02 & NCEP & MODIS & MEGAN2 & MEGAN2 & 2003 & G06 \\
\hline
\end{tabular}

transport models and satellite formaldehyde data to constrain isoprene emissions by applying the inverse modelling techniques. Our isoprene estimates varying from 520 to $672 \mathrm{Tg} \mathrm{yr}^{-1}$ over the last 3 decades with an average value of $594 \mathrm{Tg} \mathrm{yr}^{-1}$ are at the upper end of earlier estimates.

MEGAN-MACC isoprene emissions were compared to values estimated in regional studies in different parts of the world (Table 3). Emission estimates of Fu et al. (2007) and Palmer et al. (2003) were derived from GOME (Global Ozone Monitoring Experiment) formaldehyde observations. Barkley et al. (2013) derived isoprene emissions using formaldehyde vertical column measurements from OMI (Ozone Monitoring Instrument) and SCIAMACHY (Scanning imaging absorption spectrometer for atmospheric chartography). Curci et al. (2010) and Marais et al. (2012) constrained isoprene emissions with formaldehyde columns measured by OMI. The remaining studies provide bottom-up emissions calculated on the basis of detailed regional vegetation description. MEGAN-MACC isoprene is comparable to regional studies with values usually within $30 \%$ of regional estimates. Larger discrepancies of factor of 3 occur in Europe (Karl et al., 2009; Steinbrecher et al., 2009) and of a factor of 2 in Africa (Marais et al., 2012).

More detailed comparison of MEGAN-MACC isoprene with other global emission studies is addressed in Sect. 4.2.

\subsection{Spatio-temporal comparison of MEGAN-MACC isoprene with other data sets}

MEGAN-MACC isoprene estimates were compared to the results of four other studies. Table 4 summarizes general information about isoprene inventories used in the comparison. Data availability indicates the original temporal extent of each data set. However, in our study we focused on the period of 2000-2009 only.

BISA (Belgian Institute for Space Aeronomy) data sets were provided by the Belgian Institute for Space Aeronomy, and are both available on the institute's website (http://tropo.aeronomie.be/models/isoprene.htm). BISAbottom-up is an updated version of the emission inventory described in Müller et al. (2008) who applied MEGANv2.02 model driven by ERA-Interim reanalyzed meteorological fields (ECMWF) (Dee et al., 2011). In their calculations, Müller et al. replaced the built-in MEGAN canopy environment model for determination of leaf temperature and radiation fluxes by the canopy environment model MOHYCAN (MOdel for HYdrocarbon emissions by the CANopy) (Wallens, 2004).

The most recent BISA isoprene inventory, here titled as BISA-top-down, was constrained by global formaldehyde retrievals from the GOME-2 satellite instrument using the IMAGESv2 (Intermediate Model of Global Evolution of Species) chemistry transport model (Bauwens et al., 2013; 


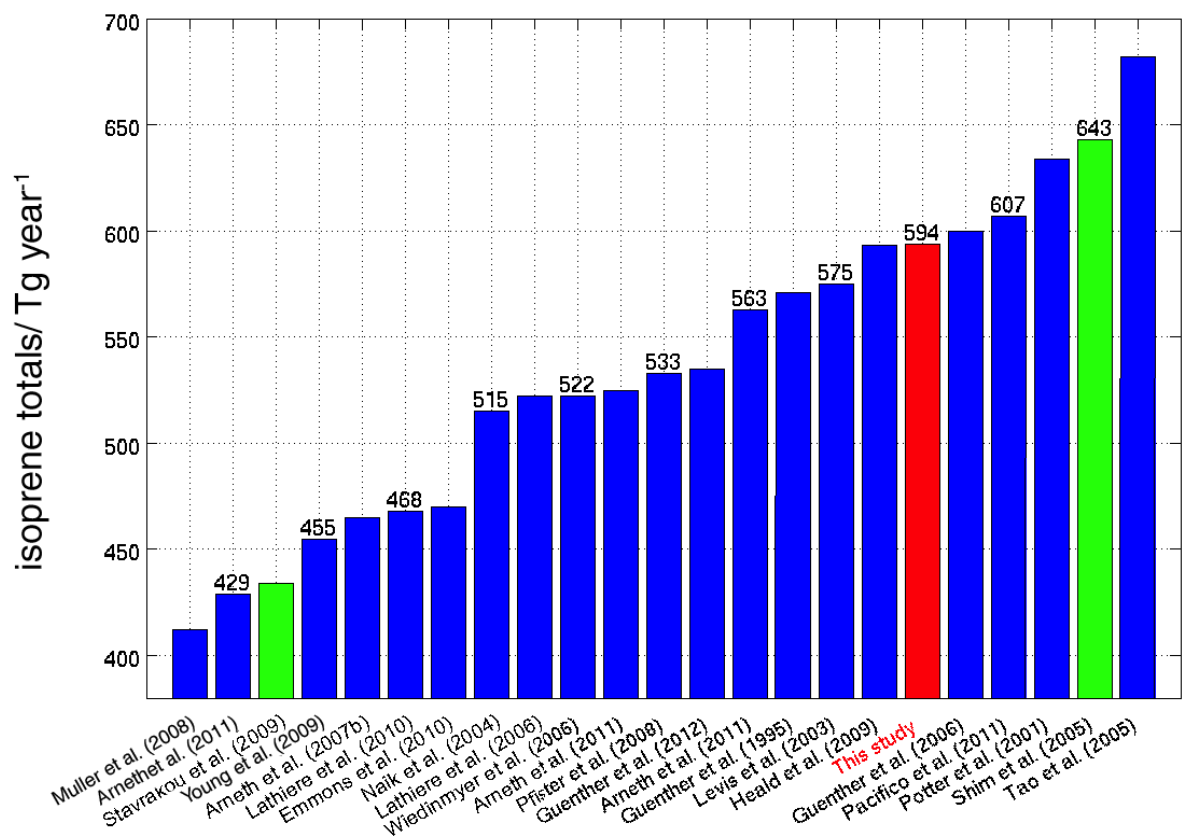

Figure 10. Isoprene global total estimated in MEGAN-MACC inventory (mean over 1980-2010, in red) compared with isoprene totals from previous studies. Studies highlighted in green used formaldehyde satellite data and inversion modelling technique to constrain isoprene emissions.

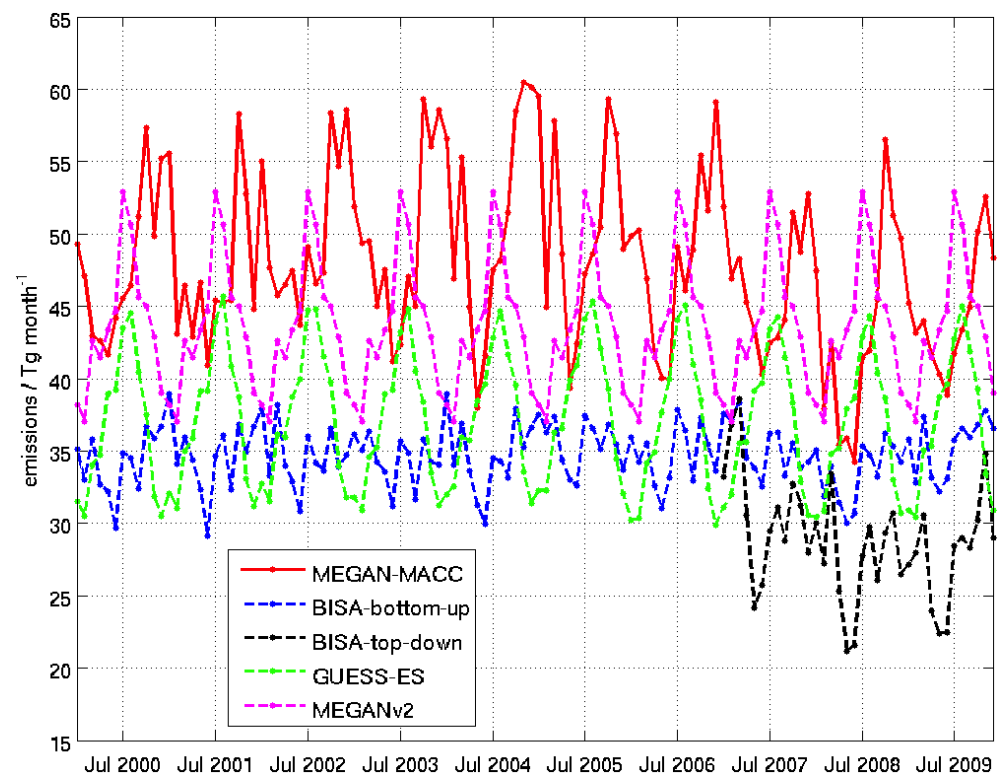

Figure 11. Global monthly total emissions of isoprene (Tg month ${ }^{-1}$ ) from different emission data sets over the period of $2000-2009$. MEGANv2 is available for the year 2003 only and is repeated for all the other years. List of emission data sets is given in the enclosed legend.

Stavrakou et al., 2014). A-priori isoprene emissions for the IMAGESv2 model were calculated by MEGANv2.1 and ERA-Interim meteorology.

Data set GUESS-ES was calculated by a coupled system of dynamic global vegetation model LPJ-GUESS (Smith et al., 2001; Sitch et al., 2003) and physiological isoprene emission algorithm (Arneth et al., 2007b). The algorithm is based on the approach of Niinemets et al. (1999) which simulates physiological processes inside the plant leading to isoprene production through electron transport rate required for isoprene synthesis. The model was driven by the meteorological fields of Climatic Research Unit (CRU) 

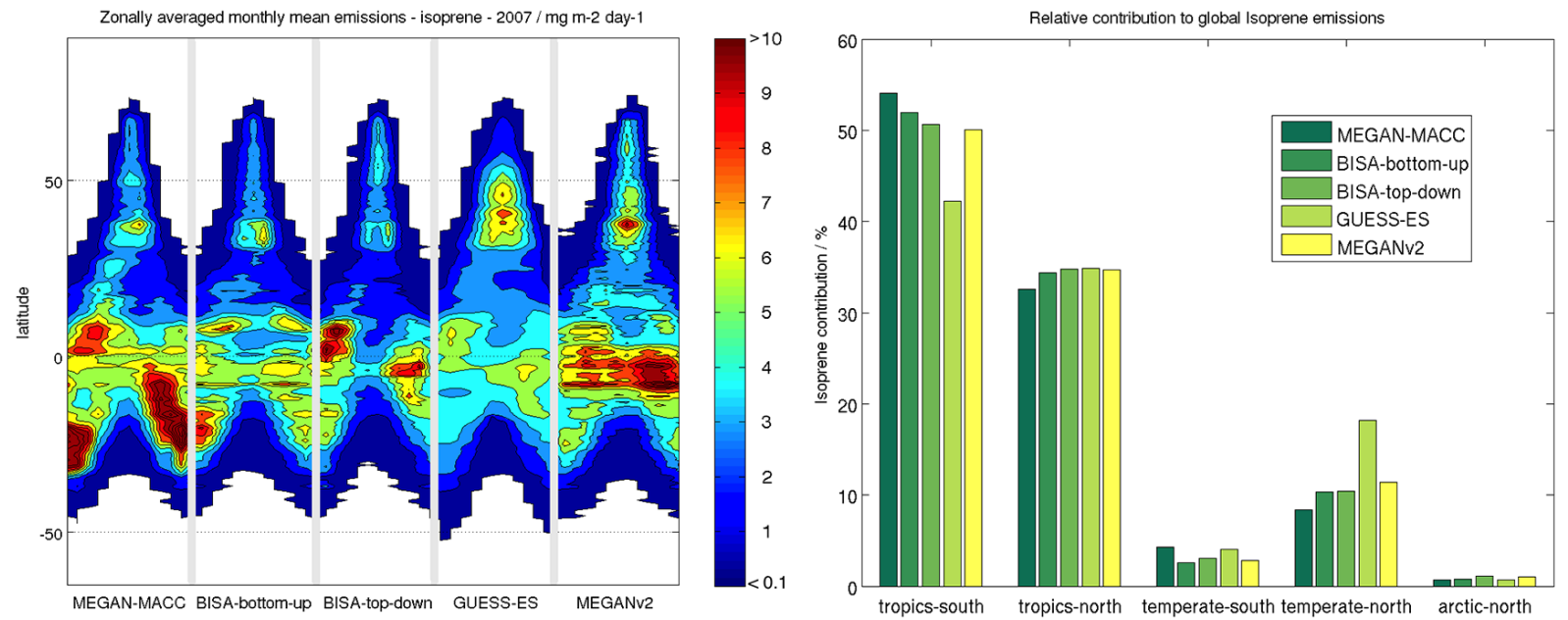

Figure 12. Comparison of zonal means of isoprene monthly emissions ( $\mathrm{mg} \mathrm{m}^{-2} \mathrm{day}^{-1}$ ) (left) and relative contributions of zonal bands to isoprene annual global total for different emission data sets in the year 2007 (2003 for MEGANv2). Colours assigned to each data set are given in the enclosed legend. The extent of zonal bands is the same as in Fig. 5.

(Mitchell and Jones, 2005), vegetation description and characteristics (LPJV) were provided by the LPJ dynamic vegetation model.

The last data set used in the comparison is MEGANv2 (Guenther et al., 2006) calculated by MEGANv2.02 forced by NCEP-DOE (updated NCEP/NCAR) reanalysis weather fields. This data set is available for the year 2003 only.

Time series of monthly global totals of isoprene during the 2000-2009 period from all five data sets are presented in Fig. 11. There is a visible shift in annual cycle of MEGAN-MACC isoprene with maximal values moved towards October/November when compared to GUESS-ES and MEGANv2 inventories, which are reaching highest emission amounts in July. The annual cycle of MEGAN-MACC isoprene is relatively similar to that of BISA-top-down. Although the magnitude of the seasonal cycle is much weaker in the BISA data sets, with no evident single maximum, the timing of the minimum (June) is identical in the BISA data sets and in MEGAN-MACC.

The discrepancy in annual cycles is caused by different intensities of emitting regions on the globe over the course of the year. As can be seen in Fig. 12, for all data sets the predominant source of isoprene is the southern tropics. Its contribution to annual global total is, however, significantly lower for GUESS-ES (42\%) when compared to MEGANbased data sets $(50-54 \%)$. These lower GUESS-ES emissions in the tropics are compensated in the northern temperate region, which contributes $18 \%$, while for the rest of the data sets this part contributes only $8-10 \%$. Figure 12 shows also a spatial distribution of regional emission activity during the year 2007 represented in zonal means of monthly isoprene emissions. The tropical region is clearly an important isoprene source for all inventories. It is pronounced in the warmest half of the year of Southern Hemisphere, es-

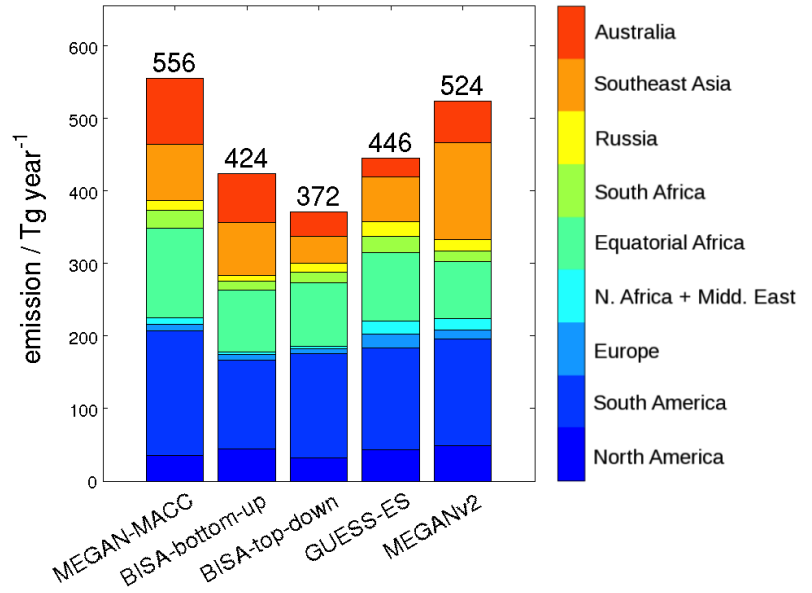

Figure 13. Absolute contributions of geographical regions to isoprene global total in MEGAN-MACC inventory and selected data sets. Graph shows results for the year 2007 (2003 for MEGANv2). Colours assigned to each region are defined in the colour bar on the right. Definition of the geographical regions is given in Fig. 8 .

pecially in MEGAN-MACC and the BISA inventories. Data sets GUESS-ES and MEGANv2 have additional strong emission sources in the northern mid latitudes active during the Northern Hemisphere's summer. In MEGANv2 data set, the tropical region is active throughout the year.

Figure 13 shows global annual totals of isoprene in the year 2007 (year 2003 for MEGANv2) and absolute contributions of each geographical region to global total. The global isoprene estimates of selected data sets are lower than MEGAN-MACC (difference of up to $-33 \%$ for BISAtop-down with respect to MEGAN-MACC). Estimates of all four other inventories are lower than MEGAN-MACC, 
Table 5. Comparison of monoterpene emissions from regional studies (left) and MEGAN-MACC (right). MEGAN-MACC emissions were extracted for the particular region and period of the regional study.

\begin{tabular}{lr}
\hline Region & monoterpenes/ $\mathrm{Tg} \mathrm{yr}^{-1}$ \\
\hline China & $4 \mid 3.1$ \\
\hline Klinger et al. (2002) & $3.2 \mid 3$ \\
Tie et al. (2006) & \\
\hline Europe & $5.4-5.9 \mid 2.6$ \\
\hline Curci et al. (2009) & $4 \mid 2.9$ \\
Karl et al. (2009) & $4 \mid 3.6$ \\
Steinbrecher et al. (2009) & \\
\hline
\end{tabular}

especially in Australia, south and equatorial Africa and South America. On the other hand, GUESS-ES and MEGANv2 are significantly higher than MEGAN-MACC in Europe and Russia, and together with BISA-bottom-up in North America. MEGANv2 reaches considerably higher isoprene values (+71\%) in Southeast Asia when compared to MEGANMACC. The difference is even higher when compared to the rest of the inventories. The graph shows that the updating of BISA emissions from bottom-up to top-down led to a substantial decrease of emissions in Southeast Asia.

Several reasons for discrepancies between MEGANMACC values and estimates of other data sets can be identified. Differences in spatial isoprene emission patterns likely originate in unequal distribution of vegetation types in different models represented by PFT maps, and/or their assignment with isoprene emission capacity values (emission potentials for MEGAN, fractions of electrons in GUESSES). Application of different PFT and LAI inputs can result in a wide range of isoprene estimates (e.g. sensitivity run S2 in this study; Pfister et al., 2008; Guenther et al., 2012). All five presented data sets were driven by different meteorological input fields. Arneth et al. (2011) showed that variation of driving input data (meteorology and vegetation description) among different models might lead to substantially different emission estimates.

More specifically, in preparation of BISA-top-down a priori emissions, Stavrakou et al. (2014) used land cover maps of Ramankutty and Foley (1999) for description of vegetation distribution in the MEGAN model. This land cover data set takes into consideration the advancing replacement of forests by agricultural croplands, which are usually lower isoprene emitters than forest ecosystems. Further, following Langford et al. (2010) they applied a significant reduction of the MEGANv2.1 isoprene emission factor for tropical forest in Southeast Asia. In both BISA inventories, MEGAN model accounted for the effect of soil moisture deficit on isoprene emission, which leads to isoprene emission reduction (Müller et al., 2008).

\subsection{Global and regional totals of other species}

Global MEGAN-MACC monoterpene emissions ranging from 89 to $102 \mathrm{Tg} \mathrm{yr}^{-1}$ over the last 30 years are similar to previous estimates of Guenther et al. (2006) who applied the MEGANv2.0 model. They are lower then those reported by Guenther et al. (2012) and significantly higher than those of Schurgers et al. (2009), which are the lowest among the values published in the literature. MEGAN-MACC monoterpene emissions were compared to regional estimates in China and Europe (Table 5) and are within $30 \%$ of regional totals, except for comparison with Curci et al. (2009) whose estimate is about a factor of 2 higher than that of MEGANMACC. Discrepancies of monoterpene emissions may arise from different approaches to monoterpene modelling. Some models use one emission factor for a group of monoterpenes as a whole, while models like MEGAN treat monoterpene species separately. Differences may therefore occur due to consideration of different monoterpene species in the final total.

Methanol emissions ranging from 121 to $138 \mathrm{Tg} \mathrm{yr}^{-1}$ are in accordance with findings of Jacob et al. (2005) and are about $25 \%$ higher than previous MEGAN model studies (Stavrakou et al., 2011; Guenther et al., 2012). Stavrakou et al. calculated global total methanol emission of $100 \mathrm{Tg} \mathrm{yr}^{-1}$ using the chemical transport model IMAGESv2 and the inversion of methanol measurements from the IASI (Infrared Atmospheric Sounding Interferometer) satellite instrument. Higher methanol values in MEGAN-MACC inventory may be a result of different meteorological fields used as input for the MEGAN model. Exceptionally high is the methanol estimate of Lathière et al. (2006) $\left(283 \mathrm{Tg} \mathrm{yr}^{-1}\right)$ calculated by dynamic global vegetation model ORCHIDEE (Organising Carbon and Hydrology in Dynamic Ecosystems) coupled with a BVOC emission model based on Guenther et al. (1995).

As shown in Fig. 14, MEGAN-MACC estimates for other $B V O C$ species fall within the range of values from the literature. Similarly to methanol, Lathière et al. (2006) report significantly higher formaldehyde values of $25 \mathrm{Tg} \mathrm{yr}^{-1}$ while MEGAN-based models (this study; Guenther et al., 2006, 2012) estimate only $\sim 5 \mathrm{Tg} \mathrm{yr}^{-1}$. Unfortunately, for species such as ethanol, propene, MBO, and toluene, there are limited studies to compare with.

\section{Comparison of model emission estimates with flux measurements in the tropics}

In order to illustrate the results of this study, we have compared the MEGAN-MACC emission estimates to flux measurements collected during two experimental campaigns located in the tropical forests in the Amazon and in Borneo. Model results were calculated by the reference MEGANMACC model run with input parameters described in 


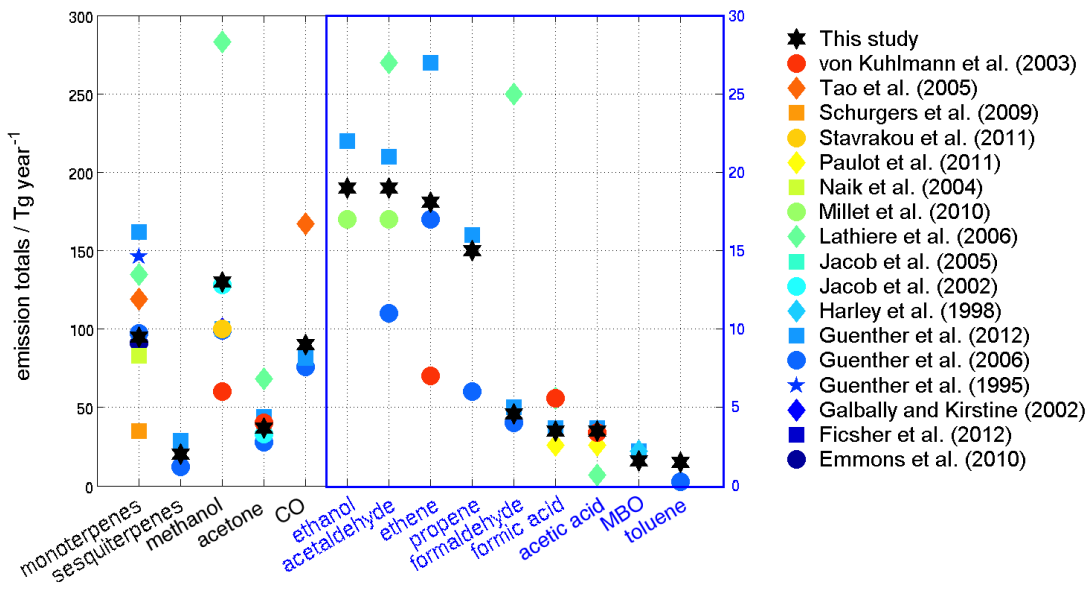

Figure 14. Comparison of MEGAN-MACC global emission totals $\left(\mathrm{Tg} \mathrm{yr}^{-1}\right)$ of species other than isoprene with emission estimates of previous studies (list of coloured symbols on the right). Note the two vertical axes in black and blue with different scales.
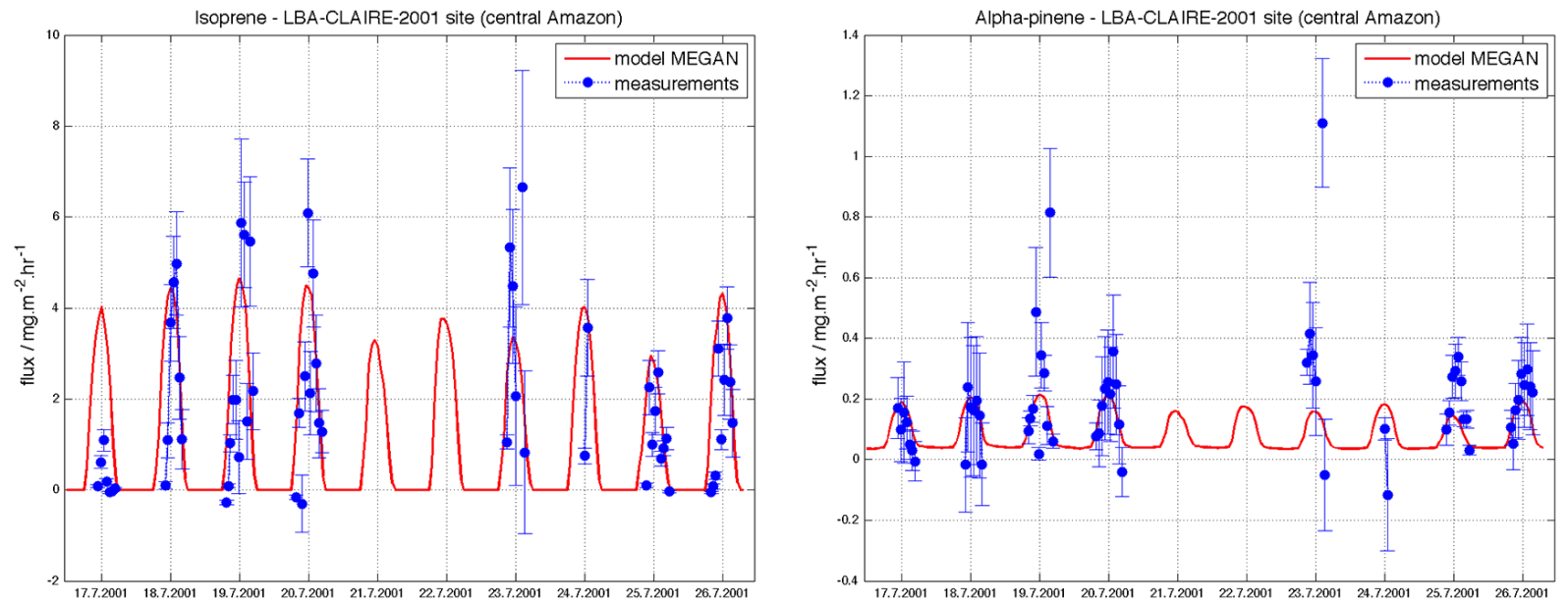

Figure 15. Comparison of isoprene (left) and $\alpha$-pinene (right) emission fluxes $\left(\mathrm{mg} \mathrm{m}^{-2} \mathrm{~h}^{-1}\right)$ measured during the LBA-CLAIRE campaign in July 2001 (blue dotted line) with flux modelled by the MEGAN model (red dashed line). Blue error bars represent the calculated uncertainty of the applied REA method, based on error propagation of the analytical and the systematic errors, respectively.

Sect. 2.2. In both cases, a mean of four grid points of the model $0.5^{\circ} \times 0.5^{\circ}$ grid closest to the location of the measurement site was used for the comparison.

MEGAN-MACC isoprene and $\alpha$-pinene model estimates were compared with fluxes measured during the Cooperative LBA Airborne Regional Experiment (LBA-CLAIRE) project, organized within the Large-scale BiosphereAtmosphere Experiment in Amazonia (LBA). The LBACLAIRE campaign took place during early dry season in July 2001 in the remote Amazonian tropical forest (Kuhn et al., 2007). The measurement site was located in the central Amazon, about $60 \mathrm{~km}$ NNW from Manaus (Reserva Biologica do Cuieiras, $2^{\circ} 35^{\prime} 33^{\prime \prime} \mathrm{S}, 60^{\circ} 12^{\prime} 27^{\prime \prime} \mathrm{W}$ ). During the campaign two ground-based micrometeorological sampling methods were adopted to calculate emission fluxes from the forest canopy. Here we show a comparison with emission fluxes obtained by relaxed eddy accumulation (REA) technique. Simultaneously, VOC fluxes were measured at the canopy-scale using a method of surface layer gradient (SLG). The two measurement systems were located on the $52 \mathrm{~m}$ high walk-up tower (K34). The measurements are representative to $2-3 \mathrm{~km}^{2}$ area around the tower (Araújo et al., 2002).

The relaxed eddy accumulation (REA) sampling system consisted of cartridges filled with graphitic carbon adsorbents installed on the K34 tower above the mean canopy top. The 30 min samples of VOCs were collected on glass cartridges which were then processed by thermal desorption gas chromatography using mass spectrometry analysis (TD-GCMS) in order to identify and quantify the observed VOCs (Kuhn et al., 2007).

Comparison of modelled and measured fluxes of isoprene and $\alpha$-pinene is presented in Fig. 15. Isoprene model results 
Table 6. Statistical comparison of model results with emission fluxes observed during the LBA-CLAIRE campaign in July 2001 in the central Amazon and during OP3 study in June-July 2008 in Borneo.

\begin{tabular}{|c|c|c|c|c|}
\hline \multirow{2}{*}{$\begin{array}{l}\text { LBA-CLAIRE } \\
2001\end{array}$} & \multicolumn{2}{|c|}{ Isoprene $\left[\mathrm{mg} \mathrm{m}^{-2} \mathrm{~h}^{-1}\right]$} & \multicolumn{2}{|c|}{$\alpha$-pinene $\left[\mathrm{mg} \mathrm{m}^{-2} \mathrm{~h}^{-1}\right]$} \\
\hline & model & obs & model & obs \\
\hline mean & 3.00 & 2.20 & 0.15 & 0.22 \\
\hline median & 3.23 & 1.71 & 0.15 & 0.18 \\
\hline 5th percentile & 0.71 & 0.09 & 0.08 & 0.04 \\
\hline 95th percentile & 4.45 & 5.82 & 0.21 & 0.47 \\
\hline std. deviation $\sigma$ & 1.18 & 1.81 & 0.04 & 0.18 \\
\hline OP3 & \multicolumn{2}{|c|}{ Isoprene $\left[\mathrm{mg} \mathrm{m}^{-2} \mathrm{~h}^{-1}\right]$} & \multicolumn{2}{|c|}{ monoterpenes $\left[\mathrm{mg} \mathrm{m}^{-2} \mathrm{~h}^{-1}\right]$} \\
\hline 2008 & model & obs & model & obs \\
\hline mean & 2.66 & 1.55 & 0.34 & 0.40 \\
\hline median & 2.91 & 1.24 & 0.36 & 0.31 \\
\hline 5th percentile & 0.003 & 0.082 & 0.16 & 0.03 \\
\hline 95th percentile & 5.22 & 4.14 & 0.49 & 1.04 \\
\hline std. deviation $\sigma$ & 1.69 & 1.35 & 0.11 & 0.37 \\
\hline
\end{tabular}

correspond fairly well to measured values (correlation coefficient of 0.4). On average over the measuring period modelled values are about $54 \%$ higher than measurements (Table 6). This difference is primarily due to measured fluxes having strong sudden decreases and occasional negative fluxes observed in early morning/late evening, which are not present in the model results. This could be an artifact of the REA sampling approach as this behaviour was not observed with eddy covariance measurements, a more direct and accurate flux technique, at a nearby site (Karl et al., 2007). MEGAN model simulates net primary emission that is released into the atmosphere, but does not include the downward flux from the air above down into the canopy (Guenther et al., 2012) while micrometeorological techniques measure net flux at the canopy level being a result of both upward and downward emission fluxes (Kuhn et al., 2007). However, since there is no production of isoprene and $\alpha$-pinene above the canopy there should be little impact from this for these two compounds. Even though MEGAN results are higher than REA observations, they are lower than emission fluxes obtained by simultaneously conducted SLG measurements, which provided isoprene flux values about $60 \%$ higher than REA. However, Kuhn et al. (2007) report a high degree of uncertainty associated with the SLG method in a complex terrain such as the vicinity of the K34 tower.

On average, MEGAN simulates the $\alpha$-pinene emissions well (Table 6), however, it does not capture the high frequency fluctuations of measured fluxes and tends to keep monoterpene emission levels above zero during night (Fig. 15). The MEGAN model algorithm for estimation of monoterpene emissions combines monoterpene dependence on light and temperature (similarly to isoprene) and to temperature only. As a result, modelled monoterpene nocturnal emissions never fall to zero and remain fairly constant during nighttime. The model defines the fraction of emissions dependent on both light and temperature with the light dependence fraction (LDF) factor (Eqs. 3 and 4). For $\alpha$-pinene LDF is set to 0.6 , which means that MEGAN expects $60 \%$ of $\alpha$-pinene emissions to be both light and temperature dependent, and $40 \%$ of the emissions to depend on temperature only. There is an increasing experimental evidence (Fig. 15; Rinne et al., 2002; Kuhn et al., 2002; Karl et al., 2004) that monoterpene emissions in the Amazonian tropical forest are strongly light dependent and the results suggest that the LDF factor for monoterpenes emitted in this region should be set close to 1 .

The inability of the model to predict the scatter of measured values for both compounds might partly originate in the coarse resolution of the model inputs, which might not reproduce well the details of local weather conditions. In addition, for $\alpha$-pinene, the flux determination using REA is more uncertain due to the lower measured fluxes. Finally, other factors than meteorology are likely to play an important role in driving the emissions, e.g. the representation of ecosystem composition which leads to the determination of emission potentials and leaf area index, biotic stress, abiotic stress such as oxidative capacity of the ambient air.

Isoprene emissions and respective atmospheric mixing ratios in South American tropical forests have a strong seasonal cycle with values about a factor of 2 higher during the dry season when compared to emission fluxes observed in the wet season (Kesselmeier et al., 2000; Kuhn et al., 2004a; Karl et al., 2007). Seasonality of isoprene over Amazonian tropical forest is consistent with the annual course of formaldehyde (HCHO) concentration, a major chemical degradation product of isoprene, derived from the satellite instruments GOME and SCIAMACHY with $\mathrm{HCHO}$ values during the dry season (August-December) 20-40\% higher than in the wet season (January-April) (Barkley et al., 2009). 

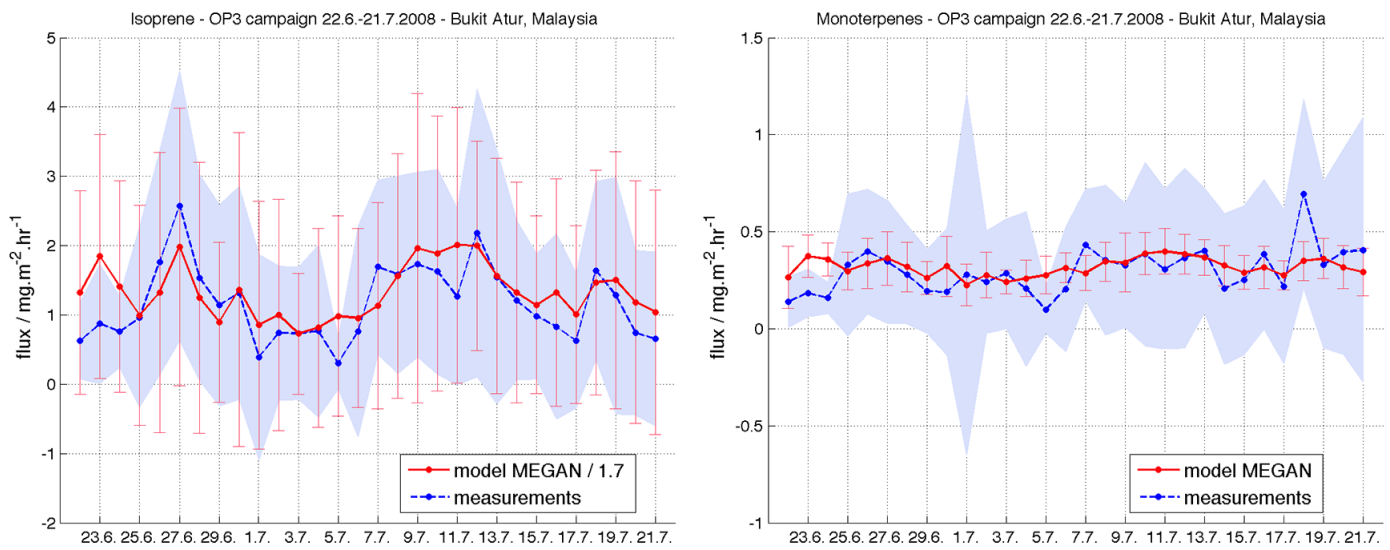

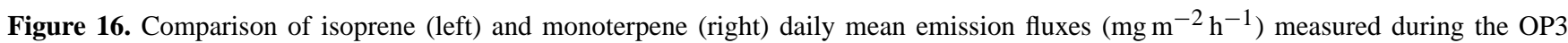
campaign in June-July 2008 (blue dashed line) with flux modelled by the MEGAN model (red line). Modelled isoprene fluxes were divided by a factor of 1.7. Blue shading and red error bars represent 1 standard deviation $(\sigma)$ from the mean measured and modelled values, resp.

Kuhn et al. (2004a) performed isoprene exchange measurements at experimental site in the Amazon Reserva Biologica Jaru, in Rondonia, Brazil ( $\left.10^{\circ} 08^{\prime} 43^{\prime \prime} \mathrm{S}, 62^{\circ} 54^{\prime} 27^{\prime \prime} \mathrm{W}\right)$. They performed dynamic branch enclosure measurements at the top of the forest canopy during the end of the dry season in September/October 1999 and compared their results with similar measurements conducted at the same site during the end of the wet season in April/May 1999 (Kuhn et al., 2002). Despite the fact that the temperature and light conditions were found to be comparable during both campaigns, Kuhn et al. (2004a) report a twofold increase of isoprene emission during the end of the dry season with respect to the end of the wet season measurements. They attribute the emission difference to higher emission rates from young mature leaves at the end of the dry season when compared to emission rates from older mature leaves present at the end of the wet season. The isoprene emission rates of different leaf developmental stages were well correlated with the leaf's gross photosynthetic capacity (Kuhn et al., 2004b). They also discuss a potential impact of long-term temperature conditions preceding both campaigns. As has been shown by Pétron et al. (2001), plants grown under higher temperatures during 3-6 weeks tend to emit substantially higher isoprene amounts. Ambient temperatures preceding the dry season campaign were $2-5^{\circ} \mathrm{C}$ higher than before the wet season campaign which could partially explain the observed increase in isoprene emissions. We have compared measured and modelled values of isoprene flux during both the wet and dry seasons. Although the actual modelled values are $\sim 40 \%$ lower than the observed ones, the seasonality expressed as the ratio between isoprene exchange rates measured during the dry (October) and wet (May) seasons (ratio $=2.1$ ) is well reproduced by the model (ratio $=2.5)$. Both leaf ageing in the course of the year and dependence of isoprene emissions on preceding temperature conditions are parameterized in the MEGAN model (Sect. 2.1; Guenther et al., 2006, 2012).
The MEGAN-MACC isoprene and monoterpene emissions were compared to emission fluxes measured during the third phase of the Oxidant and Particle Photochemical Processes above a Southeast Asian Rainforest (OP3-III, Hewitt et al., 2010). The measurement campaign took place during the dry season in June-July 2008 in the tropical rain forest of Borneo at Bukit Atur station in Danum Valley, Malaysia $\left(4^{\circ} 58^{\prime} 4^{\prime \prime} \mathrm{N}, 117^{\circ} 50^{\prime} 39^{\prime \prime} \mathrm{E}\right)$. The measurement apparatus consisted of the Proton Transfer Reaction Mass Spectrometer (PTR-MS) located on the foot of a measurement tower and connected to a heated silicon steel inlet mounted on the tower above the canopy height together with the ultrasonic anemometer (Langford et al., 2010). The method of virtual disjunct eddy covariance (vDEC) was used to calculate fluxes of VOC species. The PTR-MS was set in a way that it would alternate between the flux measurement and measurement of the VOC composition. The postprocessing of the measured data resulted in the VOC fluxes averaged over $30 \mathrm{~min}$ period (Langford et al., 2010). Comparison of daily averages of isoprene and monoterpenes calculated by the MEGAN model and measured during the OP3 campaign are shown in Fig. 16. The model is able to follow the day-to-day variability of isoprene emissions (correlation coefficient of 0.7), however, the actual isoprene values are almost factor of 2 higher than the measurements (Table 6). This discrepancy can partially be attributed to the fact that the mean model temperature is about $1.22{ }^{\circ} \mathrm{C}$ higher than the mean temperature measured at the site. Another source of difference is the emission potential of the Malaysian tropical forest. While the isoprene emission potential in the MEGAN model at the Bukit Atur station is $7 \mathrm{mg} \mathrm{m}^{-2} \mathrm{~h}^{-1}$, isoprene emission potential derived from the Bukit Atur measurements is according to Langford et al. (2010) only $1.6 \mathrm{mg} \mathrm{m}^{-2} \mathrm{~h}^{-1}$. Monoterpene emission fluxes correspond well to the flux measurements (Table 6), and for most of days, are within the band of the measurement error (blue shading in Fig. 16). For both isoprene 
and monoterpenes, the model is not capable of predicting the scatter of measured fluxes as can be seen from percentile values and standard deviation in Table 6 . This could again be caused by driving the model with input data of coarse spatial resolution which can somewhat average the emission variability.

\section{Conclusions}

We have presented a global inventory of biogenic VOCs calculated by the MEGANv2.1 model (Guenther et al., 2012) for a period of 30 years. The model estimates a total emission of $760 \mathrm{Tg}(\mathrm{C}) \mathrm{yr}^{-1}$ from terrestrial vegetation. Isoprene is the main contributor to the average emission total accounting for $70 \%\left(523 \mathrm{Tg}(\mathrm{C}) \mathrm{yr}^{-1}\right)$, followed by a group of monoterpenes (11\%), methanol (6\%), acetone (3\%), sesquiterpenes $(2.5 \%)$ and other BVOC species each accounting for less than $2 \%$. Both isoprene and monoterpenes are mainly emitted in the tropical region ( $88 \%$ and $83 \%$ of the global total, resp.). Temperate regions contribute $11 \%$ to isoprene and $16 \%$ to monoterpene global estimates. There is a substantial interannual variability in global emission totals along the 30year period. The difference between the maximal and minimal annual totals is $29 \%$ and $15 \%$ of the mean global total of isoprene and monoterpenes averaged over the last 3 decades, respectively.

We have performed a series of sensitivity-MEGAN-model runs focusing on the predominant species, isoprene, in order to quantify the impact of changes in model input data and model setting on isoprene emission. The sensitivity simulations resulted in isoprene estimates varying by up to $\pm 17 \%$ of the reference run values, except for the sensitivity run studying the impact of soil moisture deficit on isoprene (S5). Inclusion of soil moisture activity factor $\left(\gamma_{\mathrm{SM}}\right)$ parameterizing the drought conditions in the model led to an emission decrease by as much as $50 \%$ globally and even more in specific regions (e.g. Africa, Australia). Comparison with other studies in which $\gamma_{\mathrm{SM}}$ was applied showed that there are substantial differences in estimated isoprene reductions originating in the determination of wilting point values $\left(\Theta_{\mathrm{W}}\right)$, which is a crucial parameter in calculation of $\gamma_{\mathrm{SM}}$ (Eq. 7).

The MEGAN-MACC data set estimates are within the range of values presented in previous studies. Comparison of earlier studies on global and regional isoprene estimates has shown that isoprene emissions can vary within a factor of 2. The MEGAN-MACC values were therefore evaluated in more detail against four previously published inventories with a special focus on variations in spatial and temporal patterns. Substantial differences between the data sets were identified, especially in regions such as Australia, Southeast Asia and South America where the isoprene estimates differ by as much as factor of 2 to 3 .

Results of the MEGAN model were compared to flux measurements at two sites located in the tropical forest. Fluxes of isoprene and $\alpha$-pinene were compared to surface flux measurements from the LBA-CLAIRE campaign that took place in central Amazon in July 2001 and estimates of isoprene and monoterpenes were compared to observations collected during the OP3 study in June-July 2008 in Borneo. The comparison shows relatively good agreement in the Amazon. The modelled monoterpene daily mean emissions in Borneo correspond well to the measurements; however isoprene estimates are on average a factor of 1.7 higher than observations in this region. The model tends to overestimate nighttime monoterpene values. The model algorithm for monoterpene estimation combines both light and temperature dependencies and simulates positive fluxes even during night. However, tropical forests tend to have negligible nocturnal monoterpene emissions (e.g. Kuhn et al., 2007; Langford et al., 2010). Comparison with measured data during wet and dry season in the Amazon has shown that MEGAN model simulates well the seasonal variability of isoprene emissions.

The MEGAN-MACC emission estimates were shown to be comparable with findings of earlier studies as well as with surface flux measurements. However, several concerns regarding the reference isoprene emissions remain. The sensitivity run accounting for the impact of drought on isoprene emissions showed considerable emission reductions in South America, central Africa and northern Australia implying that MEGAN-MACC isoprene emissions might be overestimated in these regions if the simulated reduction due to drought is realistic. Recent flux measurements obtained during the OP3 study over the tropical forest in Malaysia (Langford et al., 2010) suggest that MEGAN model calculations in Southeast Asia might be overestimated due to utilization of emission potential value, which was found to be up to factor of 4 higher than the one measured in the field. Emission reduction in this region has also been supported by the study of Stavrakou et al. (2014) who constrained isoprene emissions using the inversion of formaldehyde satellite retrievals. Nevertheless, more observations on isoprene and other BVOCs in different parts of the world are needed for a better emission quantification and for a better understanding of the different factors driving the emissions of all these species. We see a great potential in using the satellite observations to constrain or derive biogenic VOC emissions. However, previous studies have shown inconsistencies in emission estimates suggesting that use of satellite data for these purposes is still connected to uncertainties. In order to increase accuracy of these methods, more investigation is needed in the validation of data from different satellite instruments, in evaluation of dependence of the method on a priori emissions and on chemical scheme applied.

Acknowledgements. This study was funded by the European Commission under the EU Seventh Research Framework Programme, under grant agreements no. 283576 (MACC II Project) and no. 265148 (PEGASOS project). A. Guenther was supported under the Laboratory Directed Research and Development Program 
at PNNL. TS and JFM were supported by projects PRODEX-A3C funded by the Belgian Science Policy Office and GlobEmission funded by ESA. MERRA data were provided by the Global Modeling and Assimilation Office (GMAO) at NASA Goddard Space Flight Center through the NASA GES DISC online archive. The satellite derived PAR data were provided by the University of Maryland, Department of Atmospheric and Oceanic Science, Radiation Budget team (R. T. Pinker, PI). The Large-Scale Biosphere-Atmosphere Experiment in Amazonia - Cooperative LBA Airborne Regional Experiment (LBA-CLAIRE-2001) was partially funded by the Max Planck Institute for Chemistry in Mainz, Germany. The National Center for Atmospheric Research is funded by the National Science Foundation. We thank A. Arneth for her advice on the manuscript and on the generation of the GUESS-ES data set, as well as the two anonymous reviewers and the editor for their constructive comments and suggestions.

Edited by: W. Lahoz

\section{References}

Araújo, A., Nobre, A., Kruijt, B., Elbers, J., Dallarosa, R., Stefani, P., Von Randow, C., Manzi, A., Culf, A., Gash, J., Valentini, R., and Kabat, P.: Comparative measurements of carbon dioxide fluxes from two nearby towers in a central Amazonian rainforest: the Manaus LBA site, J. Geophys. Res., 107, 8090, doi:10.1029/2001JD000676, 2002.

Arneth, A., Miller, P. A., Scholze, M., Hickler, T., Schurgers, G., Smith, B., and Prentice, I. C.: $\mathrm{CO}_{2}$ inhibition of global terrestrial isoprene emissions: Potential implications for atmospheric chemistry, Geophys. Res. Lett., 34, L18813, doi:10.1029/2007GL030615, 2007a.

Arneth, A., Niinemets, Ü., Pressley, S., Bäck, J., Hari, P., Karl, T., Noe, S., Prentice, I. C., Serça, D., Hickler, T., Wolf, A., and Smith, B.: Process-based estimates of terrestrial ecosystem isoprene emissions: incorporating the effects of a direct $\mathrm{CO}_{2}$-isoprene interaction, Atmos. Chem. Phys., 7, 31-53, doi:10.5194/acp-7-31-2007, 2007b.

Arneth, A., Schurgers, G., Lathiere, J., Duhl, T., Beerling, D. J., Hewitt, C. N., Martin, M., and Guenther, A.: Global terrestrial isoprene emission models: sensitivity to variability in climate and vegetation, Atmos. Chem. Phys., 11, 8037-8052, doi:10.5194/acp-11-8037-2011, 2011.

Ashworth, K., Wild, O., and Hewitt, C. N.: Sensitivity of isoprene emissions estimated using MEGAN to the time resolution of input climate data, Atmos. Chem. Phys., 10, 1193-1201, doi:10.5194/acp-10-1193-2010, 2010.

Atkinson, R. and Arey, J.: Gas-phase tropospheric chemistry of biogenic volatile organic compounds: a review, Atmos. Environ., 37 , 197-219, 2003.

Barkley, M. P., De Smedt, I., Van Roozendael, M., Kurosu, T. P., Chance, K., Arneth, A., Hagberg, D., Guenther, A., Paulot, F., Marias, E., and Mao, J.: Top-down isoprene emissions over tropical South America inferred from SCIAMACHY and OMI formaldehyde columns, J. Geophys. Res.-Atmos., 118, 6849_ 6868, doi:10.1002/jgrd.50552, 2013.

Barkley, M. P., Palmer, P. I., De Smedt, I., Karl, T., Guenther, A., and Van Roozendael, M.: Regulated large-scale annual shut- down of Amazonian isoprene emissions?, Geophys. Res. Lett., 36, L04803, doi:10.1029/2008GL036843, 2009.

Bauwens, M., Stavrakou, T., Müller, J.-F., De Smedt, I., and Van Roozendael, M.: Satellite-based isoprene emission estimates (2007-2012) from the GlobEmission project, in: Proceedings of the ACCENT-Plus Symposium, Atmospheric Composition Change - Policy Support and Science, Session on Short lived pollutants, climate and air quality, Urbino, Italy, 17-20 September, 2013.

Brasseur, G. P., Kiehl, J. T., Müller, J.-F., Schneider, T., Cgranier, C., Tie, X., and Hauglustaine, D.: Past and future changes in global tropospheric ozone: Impact on radiative forcing, Geophys. Res. Lett., 25, 3807-3810, 1998.

Brilli, F., Barta, C., Fortunati, A., Lerdau, M., Loreto, F., and Centritto, M.: Response of isoprene emission and carbon metabolism to drought in white poplar (Populus alba) saplings, New Phytol., 175, 244-254, 2007.

Chalita, S., Hauglustaine, D. A., Le Treut, H., and Müller, J.-F.: Radiative forcing due to increased tropospheric ozone concentrations, Atmos. Environ., 30, 1641-1646, 1996.

Chen, F. and Dudhia, J.: Coupling an advanced land surfacehydrology model with the Penn State-NCAR MM5 modeling system, Part I: Model implementation and sensitivity, Mon. Weather Rev., 129, 569-585, 2001.

Curci, G., Beekman, M., Vautard, R., Smiatek, G., and Steinbrecher, R.: Modelling study of the impact of isoprene and terpene biogenic emissions on European ozone levels, Atmos. Environ., 43, 1444-1455, 2009.

Curci, G., Palmer, P. I., Kurosu, T. P., Chance, K., and Visconti, G.: Estimating European volatile organic compound emissions using satellite observations of formaldehyde from the Ozone Monitoring Instrument, Atmos. Chem. Phys., 10, 11501-11517, doi:10.5194/acp-10-11501-2010, 2010.

Dee, D., Uppala, S., Simmons, A., Berrisford, P., Poli, P., Kobayashi, S., Andrae, U., Balmaseda, M., Balsamo, G., Bauer, P., Bechtold, P., Beljaars, A. C. M., van de Berg, L., Bidlot, J., Bormann, N., Delsol, C., Dragani, R., Fuentes, M., Geer, A. J., Haimberger, L., Healy, S. B., Hersbach, H., Hólm, E. V., Isaksen, L., Kållberg, P., Köhler, M., Matricardi, M., McNally, A. P., Monge-Sanz, B. M., Morcrette, J.-J., Park, B.K., Peubey, C., de Rosnay, P., Tavolato, C., Thépaut, J.-N., and Vitart, F.: The ERA-Interim reanalysis: configuration and performance of the data assimilation system, Q. J. Roy. Meteor. Soc., 137, 553-597, 2011.

Emmons, L. K., Walters, S., Hess, P. G., Lamarque, J.-F., Pfister, G. G., Fillmore, D., Granier, C., Guenther, A., Kinnison, D., Laepple, T., Orlando, J., Tie, X., Tyndall, G., Wiedinmyer, C., Baughcum, S. L., and Kloster, S.: Description and evaluation of the Model for Ozone and Related chemical Tracers, version 4 (MOZART-4), Geosci. Model Dev., 3, 43-67, doi:10.5194/gmd3-43-2010, 2010.

Fischer, E. V., Jacob, D. J., Millet, D. B., Yantosca, R. M., and Mao, J.: The role of the ocean in the global atmospheric budget of acetone, Geophys. Res. Lett., 39, L01807, doi:10.1029/2011GL050086, 2012.

Fu, T.-M., Jacob, D. J., Palmer, P. I., Chance, K., Wang, Y. X., Barletta, B., Blake, D. R., Stanton, J. C., and Pilling, M. J.: Spacebased formaldehyde measurements as constraints on volatile organic compound emissions in east and south Asia and im- 
plications for ozone, J. Geophys. Res.-Atmos., 112, D06312, doi:10.1029/2006JD007853, 2007.

Galbally, I. E., and Kirstine, W.: The production of methanol by flowering plants and the global cycle of methanol, J. Atmos. Chem., 43, 195-229, 2002.

Gauss, M., Myhre, G., Isaksen, I. S. A., Grewe, V., Pitari, G., Wild, O., Collins, W. J., Dentener, F. J., Ellingsen, K., Gohar, 1. K., Hauglustaine, D. A., Iachetti, D., Lamarque, J-F., Manchini, E., Mickley, 1. J., Prather, M. J., Pyle, J. A., Sanderson, M. G., Shine, K. P., Stevenson, D. S., Sudo, K., Szopa, S., and Zeng, G.: Radiative forcing since preindustrial times due to ozone change in the troposphere and the lower stratosphere, Atmopsheric Chemistry and Physics, 6, 575-599, doi:10.5194/acp6-575-2006, 2006.

Gent, P. R., Danabasoglu, G., Donner, L. J., Holland, M. M., Hunke, E. C., Jayne, S. R., Lawrence, D. M., Neale, R. B., Rasch, P. J., Vertenstein, M., Worley, P. H, Yang, Z.-L., and Zhang, M.: The Community Climate System Model version 4, J. Climate, 24, 4973-4991, doi:10.1175/2011JCLI4083.1, 2011.

Granier, C., Pétron, G., Müller, J.-F., and Brasseur, G.: The impact of natural and anthropogenic hydrocarbons on the tropospheric budget of carbon monoxide, Atmos. Environ., 34, 5255-5270, 2000 .

Griffin, R. J., David R, C. I., Seinfeld, J. H., and Dabdub, D.: Estimate of global atmospheric organic aerosol from oxidation of biogenic hydrocarbons, Geophys. Res. Lett., 26, 2721-2724, 1999.

Guenther, A., Hewitt, C. N., Erickson, D., Fall, R., Geron, C., Graedel, T., Harley, P., Klinger, L., Lerdau, M., McKay, W. A., Pierce, T., Scholes, B., Steinbrecher, R., Tallamraju, R., Taylor, J., and Zimmerman, P.: A global model of natural volatile organic compound emissions, J. Geophys. Res., 100, 8873-8892, 1995.

Guenther, A., Baugh, B., Brasseur, G., Greenberg, J., Harley, P., Klinger, L., Serça, D., and Vierling, L.: Isoprene emission estimates and uncertainties for the Central African EXPRESSO study domain, J. Geophys. Res., 104, 30625-30639, 1999.

Guenther, A., Geron, C., Pierce, T., Lamb, B., Harley, P., and Fall, R.: Natural emissions of non-methane volatile organic compounds, carbon monoxide, and oxides of nitrogen from North America, Atmos. Environ., 34, 2205-2230, 2000.

Guenther, A., Karl, T., Harley, P., Wiedinmyer, C., Palmer, P. I., and Geron, C.: Estimates of global terrestrial isoprene emissions using MEGAN (Model of Emissions of Gases and Aerosols from Nature), Atmos. Chem. Phys., 6, 3181-3210, doi:10.5194/acp-63181-2006, 2006.

Guenther, A. B., Monson, R. K., and Fall, R.: Isoprene and monoterpene emission rate variability: observations with eucalyptus and emission rate algoritm development, J. Geophys. Res., 96, 10799-10808, 1991.

Guenther, A. B., Zimmerman, P. R., Harley, P. C., Monson, R. K., and Fall, R.: Isoprene and monoterpene emission rate variability: model evaluations and sensitivity analyses, J. Geophys. Res., 98, 12609-12617, 1993.

Guenther, A. B., Jiang, X., Heald, C. L., Sakulyanontvittaya, T., Duhl, T., Emmons, L. K., and Wang, X.: The Model of Emissions of Gases and Aerosols from Nature version 2.1 (MEGAN2.1): an extended and updated framework for modeling biogenic emis- sions, Geosci. Model Dev., 5, 1471-1492, doi:10.5194/gmd-51471-2012, 2012.

Harley, P., Fridd-Stroud, V., Greenberg, J., Guenther, A., and Vasconcellos, P.: Emission of 2-methyl-3-buten-2-ol by pines: A potentially large natural source of reactive carbon to the atmosphere, J. Geophys. Res., 103, 25479-25486, 1998.

Heald, C. L., Henze, D. K., Horowitz, L. W., Feddema, J., Lamarque, J.-F., Guenther, A., Hess, P. G., Vitt, F., Seinfeld, J. H., Goldstein, A. H., and Fung, I.: Predicted change in global secondary organic aerosol concentrations in response to future climate, emissions, and land use change, J. Geophys. Res.-Atmos., 113, D05211, doi:10.1029/2007JD009092, 2008.

Heald, C. L., Wilkinson, M. J., Monson, R. K., Alo, C. A., Wang, G., and Guenther, A.: Response of isoprene emission to ambient $\mathrm{CO}_{2}$ changes and implications for global budgets, Global Change Biol., 15, 1127-1140, 2009.

Hewitt, C. N., Lee, J. D., MacKenzie, A. R., Barkley, M. P., Carslaw, N., Carver, G. D., Chappell, N. A., Coe, H., Collier, C., Commane, R., Davies, F., Davison, B., DiCarlo, P., Di Marco, C. F., Dorsey, J. R., Edwards, P. M., Evans, M. J., Fowler, D., Furneaux, K. L., Gallagher, M., Guenther, A., Heard, D. E., Helfter, C., Hopkins, J., Ingham, T., Irwin, M., Jones, C., Karunaharan, A., Langford, B., Lewis, A. C., Lim, S. F., MacDonald, S. M., Mahajan, A. S., Malpass, S., McFiggans, G., Mills, G., Misztal, P., Moller, S., Monks, P. S., Nemitz, E., Nicolas-Perea, V., Oetjen, H., Oram, D. E., Palmer, P. I., Phillips, G. J., Pike, R., Plane, J. M. C., Pugh, T., Pyle, J. A., Reeves, C. E., Robinson, N. H., Stewart, D., Stone, D., Whalley, L. K., and Yin, X.: Overview: oxidant and particle photochemical processes above a south-east Asian tropical rainforest (the $\mathrm{OP} 3$ project): introduction, rationale, location characteristics and tools, Atmos. Chem. Phys., 10, 169-199, doi:10.5194/acp10-169-2010, 2010.

Hoffmann, T., Odum, J. R., Bowman, F., Collins, D., Klockow, D., Flagan, R. C., and Seinfeld, J. H.: Formation of organic aerosols from the oxidation of biogenic hydrocarbons, J. Atmos. Chem., 26, 189-222, 1997.

Houweling, S., Dentener, F., and Lelieveld, J.: The impact of nonmethane hydrocarbon compounds on tropospheric photochemistry, J. Geophys. Res., 103, 10673-10696, 1998.

Jacob, D. J., Field, B. D., Jin, E., Bey, I., Li, Q., Logan, J., Yantosca, R. M. and Singh, H. B.: Atmospheric budget of acetone, J. Geophys. Res.-Atmos., 107, doi:10.1029/2001JD000694, 2002.

Jacob, D. J., Field, B. D., Li, Q., Blake, D. R., De Gouw, J., Warneke, C., Hansel, A., Wisthaler, A., Singh, H. B., and Guenther, A.: Global budget of methanol: constraints from atmospheric observations, J. Geophys. Res.-Atmos., 110, D08303, doi:10.1029/2004JD005172, 2005.

Jacovides, C., Tymvios, F., Asimakopoulos, D., Theofilou, K., and Pashiardes, S.: Global photosynthetically active radiation and its relationship with global solar radiation in the Eastern Mediterranean basin, Theor. Appl. Climatol., 74, 227-233, 2003.

Karl, M., Guenther, A., Köble, R., Leip, A., and Seufert, G.: A new European plant-specific emission inventory of biogenic volatile organic compounds for use in atmospheric transport models, Biogeosciences, 6, 1059-1087, doi:10.5194/bg-6-1059-2009, 2009.

Karl, T., Potosnak, M., Guenther, A., Clark, D., Walker, J., Herrick, J. D. and Geron, C.: Exchange processes of volatile organic compounds above a tropical rain forest: Implications for model- 
ing tropospheric chemistry above dense vegetation, J. Geophys. Res., 109, D18306, doi:10.1029/2004JD004738, 2004.

Karl, T., Guenther, A., Yokelson, R. J., Greenberg, J., Potosnak, M., Blake, D. R., and Artaxo, P.: The tropical forest and fire esmissions experiment: emission, chemistry, and transport of biogenic volatile organic compounds in the lower atmospehere over Amazonia, J. Geophys. Res., 112, D18302, doi:10.1029/2007JD008539, 2007.

Keeling, R. F., Piper, S. C., Bollenbacher, A. F., and Walker, S. J.: Monthly atmospheric $\mathrm{CO}_{2}$ concentrations (ppm) derived from flask air samples. Scripps $\mathrm{CO}_{2}$ Program, Tech. rep., Scripps Institution of Oceanography (SIO), University of California, La Jolla, available at: http://scrippsco2.ucsd.edu (last access: 25 April 2014), 2012.

Kesselmeier, J. and Staudt, M.: Biogenic Volatile Organic Compounds (VOC): an overview on emission, physiology and ecology, J. Atmos. Chem., 33, 23-88, 1999.

Kesselmeier, J., Kuhn, U., Wolf, A., Andreae, M., Ciccioli, P., Brancaleoni, E., Frattoni, M., Guenther, A., Greenberg, J., De Castro Vasconcellos, P., de Oliva, T., Tavares, T. and Artaxo, P.: Atmospheric volatile organic compounds (VOC) at a remote tropical forest site in central Amazonia, Atmos. Environ., 34, 40634072, 2000.

Klinger, L., Li, Q.-J., Guenther, A., Greenberg, J., Baker, B., and Bai, J.-H.: Assessment of volatile organic compound emissions from ecosystems of China, J. Geophys. Res.-Atmos., 107, 4603, doi:10.1029/2001JD001076, 2002.

Kuhn, U., Rottenberger, S., Biesenthal, T., Wolf, A., Schebeske, G., Ciccioli, P., Brancaleoni, E., Frattoni, M., Tavares, T., and Kesselmeier, J.: Isoprene and monoterpene emissions of Amazonian tree species during the wet season: direct and indirect investigations on controlling environmental functions, J. Geophys. Res., 107, 8071, doi:10.1029/2001JD000978, 2002.

Kuhn, U., Rottenberger, S., Biesenthal, T., Wolf, A., Schebeske, G., Ciccioli, P., Brancaleoni, E., Frattoni, M., Tavares, T., and Kesselmeier, J.: Seasonal differences in isoprene and lightdependent monoterpene emission by Amazonian tree species, Global Change Biol., 10, 663-682, 2004a.

Kuhn, U., Rottenberger, S., Biesenthal, T., Wolf, A., Schebeske, G., Ciccioli, P., and Kesselmeier, J.: Strong correlation between isoprene emission and gross photosynthetic capacity during leaf phenology of the tropical tree species Hymenaea courbaril with fundamental changes in volatile organic compounds emission composition during early leaf development, Plant Cell Environ., 27, 1469-1485, 2004b.

Kuhn, U., Andreae, M. O., Ammann, C., Araújo, A. C., Brancaleoni, E., Ciccioli, P., Dindorf, T., Frattoni, M., Gatti, L. V., Ganzeveld, L., Kruijt, B., Lelieveld, J., Lloyd, J., Meixner, F. X., Nobre, A. D., Pöschl, U., Spirig, C., Stefani, P., Thielmann, A., Valentini, R., and Kesselmeier, J.: Isoprene and monoterpene fluxes from Central Amazonian rainforest inferred from towerbased and airborne measurements, and implications on the atmospheric chemistry and the local carbon budget, Atmos. Chem. Phys., 7, 2855-2879, doi:10.5194/acp-7-2855-2007, 2007.

Langford, B., Misztal, P. K., Nemitz, E., Davison, B., Helfter, C., Pugh, T. A. M., MacKenzie, A. R., Lim, S. F., and Hewitt, C. N.: Fluxes and concentrations of volatile organic compounds from a South-East Asian tropical rainforest, Atmos. Chem. Phys., 10, 8391-8412, doi:10.5194/acp-10-8391-2010, 2010.
Lathière, J., Hauglustaine, D. A., Friend, A. D., De NobletDucoudré, N., Viovy, N., and Folberth, G. A.: Impact of climate variability and land use changes on global biogenic volatile organic compound emissions, Atmos. Chem. Phys., 6, 2129-2146, doi:10.5194/acp-6-2129-2006, 2006.

Lathière, J., Hewitt, C. N., and Beerling, D. J.: Sensitivity of isoprene emissions from the terrestrial biosphere to 20th century changes in atmospheric $\mathrm{CO}_{2}$ concentration, climate, and land use, Global Biochem. Cy., 24, GB1004, doi:10.1029/2009GB003548, 2010.

Lawrence, D. M., Oleson, K. W., Flanner, M. G., Thornton, P. E., Swenson, S. C., Lawrence, P. J., Zeng, X., Yang, Z.-L., Levis, S., Sakaguchi, K., Bonan, G. B. and Slater, A. G.: Parameterization improvements and functional and structural advances in version 4 of the Community Land Model, J. Adv. Model. Earth Syst., 3, M03001, doi:10.1029/2011MS000045, 2011.

Lawrence, P. J. and Chase, T. N.: Representing a new MODIS consistent land surface in the Community Land Model (CLM 3.0), J. Geophys. Res.-Biogeo., 112, G01023, doi:10.1029/2006JG000168, 2007.

Levis, S., Wiedinmyer, C., Bonan, G. B., and Guenther, A.: Simulating biogenic volatile organic compound emissions in the Community Climate System Model, J. Geophys. Res., 108, doi:10.1029/2002JD003203, 2003.

Limbeck, A., Kulmala, M., and Puxbaum, H.: Secondary organic aerosol formation in the atmosphere via heterogenous reaction of gaseous isoprene on acidic particles, Geophys. Res. Lett., 30, 1996, doi:10.1029/2003GL017738, 2003.

Marais, E. A., Jacob, D. J., Kurosu, T. P., Chance, K., Murphy, J. G., Reeves, C., Mills, G., Casadio, S., Millet, D. B., Barkley, M. P., Paulot, F., and Mao, J.: Isoprene emissions in Africa inferred from OMI observations of formaldehyde columns, Atmos. Chem. Phys., 12, 6219-6235, doi:10.5194/acp12-6219-2012, 2012.

Martin, M., Stirling, C., Humphries, S., and Long, S.: A processbased model to predict the effects of climatic change on leaf isoprene emission rates, Ecol. Model., 131, 161-174, 2000.

Millet, D. B., Jacob, D. J., Boersma, K. F., Fu, T.-M., Kurosu, T. P., Chance, K., Heald, C. L., and Guenther, A.: Spatial distribution of isoprene emissions from North America derived from formaldehyde column measurements by the OMI satellite sensor, J. Geophys. Res.-Atmos., 113, D02307, doi:10.1029/2007JD008950, 2008.

Millet, D. B., Guenther, A., Siegel, D. A., Nelson, N. B., Singh, H. B., de Gouw, J. A., Warneke, C., Williams, J., Eerdekens, G., Sinha, V., Karl, T., Flocke, F., Apel, E., Riemer, D. D., Palmer, P. I., and Barkley, M.: Global atmospheric budget of acetaldehyde: 3-D model analysis and constraints from in-situ and satellite observations, Atmos. Chem. Phys., 10, 34053425, doi:10.5194/acp-10-3405-2010, 2010.

Mitchell, T. D. and Jones, P. D.: An improved method of constructing a database of monthly climate observations and associated high-resolution grids, Int. J. Climatol., 25, 693-712, 2005.

Müller, J.-F., Stavrakou, T., Wallens, S., De Smedt, I., Van Roozendael, M., Potosnak, M. J., Rinne, J., Munger, B., Goldstein, A., and Guenther, A. B.: Global isoprene emissions estimated using MEGAN, ECMWF analyses and a detailed canopy environment model, Atmos. Chem. Phys., 8, 1329-1341, doi:10.5194/acp-81329-2008, 2008. 
Naik, V., Delire, C., and Wuebbles, D. J.: Sensitivity of global biogenic isoprenoid emissions to climate variability and atmospheric $\mathrm{CO}_{2}$, J. Geophys. Res.-Atmos., 109, D06301, doi:10.1029/2003JD004236, 2004.

Niinemets, Ü., Tenhunen, J. D., Harley, P. C., and Steinbrecher, R.: A model of isoprene emission based on energetic requirements for isoprene synthesis and leaf photosynthetic properties for Liquidambar and Quercus, Plant Cell Environ., 22, 1319-1335, 1999.

Pacifico, F., Harrison, S. P., Jones, C. D., Arneth, A., Sitch, S., Weedon, G. P., Barkley, M. P., Palmer, P. I., Serça, D., Potosnak, M., Fu, T-M., Goldstein, A., Bai, J., and Schurgers, G.: Evaluation of a photosynthesis-based biogenic isoprene emission scheme in JULES and simulation of isoprene emissions under presentday climate conditions, Atmos. Chem. Phys., 11, 4371-4389, doi:10.5194/acp-11-4371-2011, 2011.

Palmer, P. I., Jacob, D. J., Fiore, A. M., and Martin, R. V.: Mapping isoprene emissions over North America using formaldehyde column observations from space, J. Geophys. Res., 108, 4180, doi:10.1029/2002JD002153, 2003.

Papaioannou, G., Papanikolaou, N., and Retalis, D.: Relationships of photosynthetically active radiation and shortwave irradiance, Theor. Appl. Climatol., 48, 23-27, 1993.

Paulot, F., Wunch, D., Crounse, J. D., Toon, G. C., Millet, D. B., DeCarlo, P. F., Vigouroux, C., Deutscher, N. M., González, A. G., Notholt, J., Warneke, T., Hannigan, J. W., Warneke, C., de Gouw, J. A., Dunlea, E. J., De Mazière, M., Griffith, D. W. T., Bernath, P., Jimenez, J. L., and Wennberg, P. O.: Importance of secondary sources in the atmospheric budgets of formic and acetic acids, Atmos. Chem. Phys., 11, 1989-2013, doi:10.5194/acp-11-1989-2011, 2011.

Pegoraro, E., Rey, A., Bobich, E. G., Barron-Gafford, G., Grieve, K. A., Malhi, Y., and Murthy, R.: Effect of elevated $\mathrm{CO}_{2}$ concentration and vapour pressure deficit on isoprene emission from leaves of Populus deltoides during drought, Funct. Plant Biol., 31, 1137-1147, 2004a.

Pegoraro, E., Rey, A., Greenberg, J., Harley, P., Grace, J., Malhi, Y., and Guenther, A.: Effect of drought on isoprene emission rates from leaves of Quercus virginiana Mill., Atmos. Environ., 38, 6149-6156, 2004b.

Pegoraro, E., Potosnak, M. J., Monson, R. K., Rey, A., BarronGafford, G., and Osmond, C. B.: The effect of elevated $\mathrm{CO}_{2}$, soil and atmospheric water deficit and seasonal phenology on leaf and ecosystem isoprene emission, Funct. Plant Biol., 34, 774$784,2007$.

Pétron, G., Harley, P., Greenberg, J., and Guenther, A.: Seasonal temperature variations influence isoprene emission, Geophys. Res. Lett., 28, 1707-1710, 2001.

Pfister, G., Emmons, L., Hess, P., Lamarque, J.-F., Orlando, J., Walters, S., Guenther, A., Palmer, P., and Lawrence, P.: Contribution of isoprene to chemical budgets: a model tracer study with the NCAR CTM MOZART-4, J. Geophys. Res.-Atmos., 113, D05308, doi:10.1029/2007JD008948, 2008.

Pierce, T., Geron, C., Bender, L., Dennis, R., Tonnesen, G., and Guenther, A.: Influence on increased isoprene emissions on regional ozone modeling, J. Geophys. Res., 103, 25611-25629, 1998.

Poisson, N., Kanakidou, M., and Crutzen, P. J.: Impact of nonmethane hydrocarbons on tropospheric chemistry and the oxi- dizing power of the global troposphere: 3-dimensional modelling results, J. Atmos. Chem., 36, 157-230, 2000.

Potter, C. S., Alexander, S. E., Coughlan, J. C., and Klooster, S. A.: Modeling biogenic emissions of isoprene: exploration of model drivers, climate control algorithms, and use of global satellite observations, Atmos. Environ., 35, 6151-6165, 2001.

Pugh, T., Ashworth, K., Wild, O., and Hewitt, C.: Effects of the spatial resolution of climate data on estimates of biogenic isoprene emissions, Atmos. Environ., 70, 1-6, 2013.

Ramankutty, N. and Foley, J. A.: Estimating historical changes in global land cover: croplands from 1700 to 1992, Global Biogeochem. Cy., 13, 997-1027, 1999.

Rao, C. N.: Photosynthetically active components of global solar radiation: measurements and model computations, Arch. Meteor. Geophy. B, 34, 353-364, 1984.

Rienecker, M. M., Suarez, M. J., Gelaro, R., Todling, R., Bacmeister, J., Liu, E., Bosilovich, M. G., Schubert, S. D., Takacs, L., Kim, G.-K., Bloom, S., Junye, C., Collins, D., Conaty, A., da Silva, A., Gu, W., Joiner, J., Koster, R. D., Lucchesi, R., Molod, A., Owens, T., Pawson, S., Pegion, P., Redder, C. R., Reichle, R., Robertson, F. R., Ruddick, A. G., Sienkiewicz, M., and Woollen, J.: MERRA: NASA's modern-era retrospective analysis for research and applications, J. Climate, 24, 3624-3648, 2011.

Rinne, H. J. I., Guenther, A. B., Greenberg, J. P., and Harely, P., C.: Isoprene and monoterpene fluxes measured above Amazonian rainforest and their dependence on light and temperature, Atmos. Environ., 36, 2421-2426, 2002.

Sakulyanontvittaya, T., Duhl, T., Wiedinmyer, C., Helmig, D., Matsunaga, S., Potosnak, M., Milford, J., and Guenther, A.: Monoterpene and sesquiterpene emission estimates for the United States, Environ. Sci. Technol., 42, 1623-1629, 2008.

Sartelet, K. N., Couvidat, F., Seigneur, C., and Roustan, Y.: Impact of biogenic emissions on air quality over Europe and North America, Atmos. Environ., 53, 131-141, 2012.

Schiffer, R. and Rossow, W. B.: The International Satellite Cloud Climatology Project (ISCCP) - The first project of the World Climate Research Programme, B. Am. Meteorol. Soc., 64, 779784, 1983.

Schurgers, G., Arneth, A., Holzinger, R., and Goldstein, A. H.: Process-based modelling of biogenic monoterpene emissions combining production and release from storage, Atmos. Chem. Phys., 9, 3409-3423, doi:10.5194/acp-9-3409-2009, 2009.

Sharkey, T. D. and Loreto, F.: Water stress, temperature, and light effects on the capacity for isoprene emission and photosynthesis of kudzu leaves, Oecologia, 95, 328-333, 1993.

Shim, C., Wang, Y., Choi, Y., Palmer, P. I., Abbot, D. S., and Chance, K.: Constraining global isoprene emissions with Global Ozone Monitoring Experiment (GOME) formaldehyde column measurements, J. Geophys. Res.-Atmos., 110, D24301, doi:10.1029/2004JD005629, 2005.

Simpson, D.: Biogenic emissions in Europe 2. Implications for ozone control strategies, J. Geophys. Res., 100, 22891-22906, 1995.

Sitch, S., Smith, B., Prentice, I. C., Arneth, A., Bondeau, A., Cramer, W., Kaplan, J., Levis, S., Lucht, W., Sykes, M., Thonicke, K. and Venevsky, S.: Evaluation of ecosystem dynamics, plant geography and terrestrial carbon cycling in the LPJ dynamic global vegetation model, Global Change Biol., 9, 161185, 2003. 
Smith, B., Prentice, I. C., and Sykes, M. T.: Representation of vegetation dynamics in the modelling of terrestrial ecosystems: comparing two contrasting approaches within European climate space, Global. Ecol. Biogeogr., 10, 621-637, 2001.

Stavrakou, T., Müller, J.-F., De Smedt, I., Van Roozendael, M., van der Werf, G. R., Giglio, L., and Guenther, A.: Global emissions of non-methane hydrocarbons deduced from SCIAMACHY formaldehyde columns through 2003-2006, Atmos. Chem. Phys., 9, 3663-3679, doi:10.5194/acp-9-3663-2009, 2009.

Stavrakou, T., Guenther, A., Razavi, A., Clarisse, L., Clerbaux, C., Coheur, P.-F., Hurtmans, D., Karagulian, F., De Mazière, M., Vigouroux, C., Amelynck, C., Schoon, N., Laffineur, Q., Heinesch, B., Aubinet, M., Rinsland, C., and Müller, J.F.: First space-based derivation of the global atmospheric methanol emission fluxes, Atmos. Chem. Phys., 11, 4873-4898, doi:10.5194/acp-11-4873-2011, 2011.

Stavrakou, T., Müller, J.-F., Bauwens, M., De Smedt, I., Van Roozendael, M., Guenther, A., Wild, M., and Xia, X.: Isoprene emissions over Asia 1979-2012: impact of climate and land use changes, Atmos. Chem. Phys., 14, 4587-4605, doi:10.5194/acp-14-4587-2014, 2014.

Steinbrecher, R., Smiatek, G., Köble, R., Seufert, G., Theloke, J., Hauff, K., Ciccioli, P., Vauratd, R., and Curci, G.: Intra- and inter-annual variability of VOC emissions from natural and seminatural vegetation in Europe and neighbouring countries, Atmos. Environ., 43, 1380-1391, 2009.

Sun, Z., Hüve, K., Vislap, V., and Niinemets, Ü.: Elevated $\left[\mathrm{CO}_{2}\right]$ magnifies isoprene emissions under heat and improves thermal resistance in hybrid aspen, J. Exp. Bot., 64, 5509-5523, 2013.

Tao, Z., and Jain, A. K.: Modeling of global biogenic emissions for key indirect greenhouse gases and their response to atmospheric $\mathrm{CO}_{2}$ increases and changes in land cover and climate, J. Geophys. Res.-Atmos., 110, D21309, doi:10.1029/2005JD005874, 2005.
Taraborrelli, D., Lawrence, M., Crowley, J., Dillon, T., Gromov, S., Groß, C., Vereecken, L., and Lelieveld, J.: Hydroxyl radical buffered by isoprene oxidation over tropical forests, Nat. Geosci., 5, 190-193, 2012.

Tie, X., Li, G., Ying, Z., Guenther, A., and Madronich, S.: Biogenic emissions of isoprenoids and NO in China and comparison to anthropogenic emissions, Sci. Total Environ., 371, 238-251, 2006.

Tingey, D. T., Evans, R., and Gumpertz, M.: Effects of environmental conditions on isoprene emission from live oak, Planta, 152, 565-570, 1981.

van Donkelaar, A., Martin, R. V., Park, R. J., Heald, C. L., TzungMay Fu, Hong Liao, and Guenther, A.: Model evidence for a significant source of secondary organic aerosol from isoprene, Atmos. Environ., 41, 1267-1274, 2007.

von Kuhlmann, R., Lawrence, M. G., Crutzen, P. J., and Rasch, P. J.: A model for studies of tropospheric ozone and nonmethane hydrocarbons: Model description and ozone results, J. Geophys. Res.-Atmos., 108, 4294, doi:10.1029/2002JD002893, 2003.

Wallens, S.: Modélisation des émissions de composés organiques volatils par la végétation, Ph.D. thesis, Université Libre de Bruxelles, Brussels, 2004.

Wiedinmyer, C., Tie, X., Guenther, A., Neilson, R., and Granier, C.: Future changes in biogenic isoprene emissions: how might they affect regional and global atmospheric chemistry?, Earth Interact., 10, 1-19, 2006.

Young, P. J., Arneth, A., Schurgers, G., Zeng, G., and Pyle, J. A.: The $\mathrm{CO}_{2}$ inhibition of terrestrial isoprene emission significantly affects future ozone projections, Atmos. Chem. Phys., 9, 27932803, doi:10.5194/acp-9-2793-2009, 2009.

Yuan, H., Dai, Y., Xiao, Z., Ji, D., and Shangguan, W.: Reprocessing the MODIS Leaf Area Index products for land surface and climate modelling, Remote Sens. Environ., 115, 1171-1187, 2011.

Zeng, X.: Global vegetation root distribution for land modeling, J. Hydrometeorol., 2, 525-530, 2001. 